Ankara Üniversitesi Türk İnklâp Tarihi Enstitüsü Atatürk Yolu Dergisi S 37-38, Mayı-Kasim 2006, s. 15-53

\title{
Örgütlenmeden Eyleme Geçiş: 31 Mart Olayı
}

\author{
Dr. Necdet AYSAL *
}

\section{ÖZET}

31 Mart Olayı, II. Meşrutiyetin en ilgi çekici olaylarından birisidir. Geçmişte ve günümüzde bu olayın çıkış nedenleri hakkında ortaya atılan çok çeşitli iddialar vardır. Nitekim, geçmişin hatta günümüzün siyasal ve kişisel görüşleri arasından styrllıp gerçeğe ulaşmak hayli zordur.

13 Nisan 1909 tarihinde Ístanbul'da gerçekleşen bu olay soyut olarak ele alınırsa Kabakçı Mustafa ve Patrona Halil Ayaklanması ile benzerlik gösterilebilir. Ancak derinlemesine incelendiğinde nasıl düzenlenirse düzenlensin, oluş itibarıla Íslamcılık akımını soysuzlaştırmaya götüren gerici bir hareket olduğu çok net bir şekilde görülmektedir. Gerici örgütlenmenin sonucu olarak, devleti tam şer'i bir düzene sokma teşebbüsüdür. Bu olay, belli şahısların ve çevrelerin tahriki ile başlayarak fikri bakımdan beslenmiş ve toplumun içinde din ve mukaddesat istismarcılı̆̆ının ne kadar önemli yıkıntılar yapabileceğini açıkça göstermiştir. Olayın daha sonraki devrelerde bir irtica hadisesi olmadığ Cemiyeti'nin tahrik ve kışkırtmalarının bir eseri olduğu da ileri sürülmüştür. Fakat, olaydan önce ve sonra İstanbul ve diğer şehirlerde meydana gelen gelişmeler, bu olaya basit bir tahrik eseri damgasinin vurulmasinı engellemektedir.

Bu çalışmada, Osmanll tarihinin meşhur ve koyu bir irtica hareketi olan 31 Mart Olayı'nın çıkış nedenleri, gelişimi ve sonuçları üzerinde durulmuş ve bu olayda komuoyunun tepkisi vurgulanmaya çalışılmıştır.

Anahtar Kelimeler: II. Meşrutiyet, Ittihat ve Terakki Fırkast, Ittihâd-l Muhammedî Fırkası, Ahrar Fırkast, Volkan gazetesi, Serbesti gazetesi, Mizan gazetesi, Tanin gazetesi, Hareket Ordusu, Önyüzbaşı (Kolă̆ası) Mustafa Kemal (Atatürk), II. Abdülhamit, Mahmut Şevket Paşa, Derviş Vahdeti.

\footnotetext{
* Öğretim Görevlisi Doktor, Ankara Üniversitesi Türk İnkılap Tarihi Enstitüsü.
} 


\section{UNORGANIZED ACTIVITY TRANSITION: CASE OF 31 OF MARCH}

\section{ABSTRACT}

31 March (thirty first of March) Case is one of the most interesting event of II. Meşrutiyet (Second Constitutionalism). There are so many pretenses about the reason of origination of this event in the past and at the present time. Thus, to separate and to reach the reality of among the political and the personnel visual of the past and the nowadays is very difficult.

If we take this event as intangible which actualized in April 13, 1909, it may be similar of Kabakçı Mustafa and Patrona Halil uprising. However, if we examine inwardly however they arrange it, it occurs in a very clearly shape that consideration of occurrence, it shows the Islamic trend as an obscurantist action and makes it degenerate. As a result of obscurantist organization, to attempt the government to Islamic Regulations. This event has been started with the stimulation of some persons and their environment. It shows that exploitation of religious and the holy subjects can make very important dangers in society which sponsored with the ideas. In the future period of this event, they mentioned it wasn't and reaction event, it was the creation of provocateurs by Ittihat ve Terakki Cemiyeti. But, some developments which appeared in Istanbul and in the other cities prevent from a simp-le provocation before and after this event.

In this study, I tried to underline and emphasize the reason, development and result of the origination of the 31 March event which is the most famous and fanatic reaction of the Ottoman History.

Key Words: II. Meşrutiyet, Ittihat ve Terakki Fırkası, İttihâd-l Muhammedî Firkast, Ahrar Furkast, Volkan gazetesi, Serbesti gazetesi, Mizan gazetesi, Tanin gazetesi, Hareket Ordusu, Önyüzbaşı (Kolağası) Mustafa Kemal (Atatürk), II. Abdülhamit, Mahmut Şevket Paşa, Derviş Vahdeti.

\section{Olayın Çıkış Nedenleri ve Gelişimi}

1908 yılının son üç ayında Osmanlı Hükümeti'nin esas çabası dış politika ile ilgilidir. İç politikada ise, baş kaldırmaya başlayan irtica ve taassubu kontrol altına almak, seçim işlerini hükümetin tam tarafsızlı̆̆ı içinde sonuçlandırmak, ordu içinde taassup kışkırtmalarıyla başlayan "mektepli-alaylı" subay tartışmalarını çözümlemek, yıllardan beri hizmet sürelerini tamamlamış fakat hâlâ silah altında tutulan erlerin konumu, bunun yanı sıra yeniden asker toplanılmasıyla ortaya çıkan hoşnutsuzluklar ve birçok subayın yasak olmasına rağmen siyasal çalışmalara katılmasıyla meydana gelen sıkıntılı durumlar ile uğraşmak zorunda kalmasıdır ${ }^{1}$.

${ }^{1}$ Yusuf Hikmet Bayur, Türk inkllabı Tarihi, C. I, Ks. II, Ankara, TTK., 1991, s. 124125; Mustafa Ergün, Atatürk Devri Türk Eğitimi, Ankara, DTCF Yayınlanı, 1982, s.46. 
II. Meşrutiyet devrimi ve Kanun-u Esâsi değişiklikleriyle daha demokratik bir düzen getirme ve parlamenter rejimi yerleştirme amacı düşünülmüştü ${ }^{2}$. Fakat kısa bir süre sonra meydana gelecek olaylar, Meşrutiyetin sağlam temeller üzerine kurulmadığını gösterecektir. Çünkü Osmanlı İmparatorluğu'nda, Fransız İhtilâli'nde olduğu gibi, düşünce özgürlüğü ile beslenmiş orta sınıfa mensup bir halk yoktu. Halkın çoğunluğunu teşkil eden köylüler, henüz özgürlük bilincinden yoksundu. Endüstri gelişmemiş, ticaret ve bayındırlık tesisleri yabancıların elinde idi. Dolayısıyla halkın da cahil olması nedeniyle Meşrutiyet Devrimi, aydınlardan küçük bir grubun diğer küçük bir grupla uğraşmasından ibaret kalmıştır. Bu genel nedenlerle meşrutiyetin getirdiği özgürlük, daha ilk günden beri bir kısım halk ve basın tarafından kötüye kullanılmaya başlanmıştır ${ }^{3}$. İttihat ve Terakki Cemiyeti'nin yarı resmi gazetesi olan Tanin, özgürlük ve hak arasında gözetilmesi gerekli ilişkiyi şöyle açıklamaktadır":

"Uygar memleketlerde insanların sahip olduğu özgürlük kayıtsız ve şartsız değildir. Özgürlü̆̆̈̈n karşısında bir de hak vardır. Hiç kimse ben özgürüm diye diğerinin hakkına tecavüz edemez. Hükümet ahâlinin hakkına taarruz edemeyeceği gibi, ahâlide hükümetin hakkına saygı göstermelidir. Herkes kendiliğinden hak ve adalet sağlamaya kalkarsa memleket alt üst olur. Fena bulur".

İttihat ve Terakki'nin Meşrutiyete rağmen devlet yönetimine doğrudan doğruya katılmaması, bir yandan cemiyete karşı halk yığınları arasındaki tepkiyi geliştirirken, öte yandan söylentiler ve olayları birbirine bağlama yoluyla kamuoyu tahrik ediliyordu. Bu dönem içerisinde İstanbul'da yangınların çoğalması, bu söylentileri büsbütün arttırmıştı. Özellikle, "Çırçır Yangını" bir sorun haline getirilmiş ve şeriat hükümlerinin uygulanmaması yüzünden İstanbul'un başında belaların dolaştığı söylenmiştir. Bu arada cemiyetçi propaganda, yangınları eski hafiyelerin kundaklama faaliyetine bağlamaya çalışıyorsa da, halk daha çok bunları kıyamet gününün yaklaşma alâmeti olarak kabul ediyordu. Ayrıca, rejim değişikliği dolayısıyla bir takım çıkarlara set çekilmiş ve işten çıkarılan memurlar da doğal olarak yeni düzenin karşısına geçmişlerdi. Üstelik Meşrutiyet, sürgünlerden dönen ve daha büyük imkânlara kavuşmak isteyen aydınların bir kısmını da tatmin etmemişti ${ }^{5}$.

İşte bu nedenlerden dolayı, İttihatçılara karşı oluşan muhalefet her geçen gün genişlemekteydi. Bu arada, Meclisteki muhalefet grubu ve basının, İttihatçılara ölçüsüz bir şekilde saldırılarının siyasal ihtiraslardan başka, çeşitli çıkarların etkisi ile yapıldığını da belirtmekte yarar vardır. Bunların başında ise yabancı devletlerin çevirmiş olduğu entrikalar

${ }^{2}$ Ecvet Güresin, 31 Mart İsyanı, İstanbul, Habora Kitabevi Yay., 1969, s. 17.

${ }^{3}$ Enver Ziya Karal, Osmanlı Tarihi, İkinci Meşrutiyet ve Birinci Dünya Savaşı (19081918), C. IX, 3. B., Ankara, TTK., 1988, s. 79.

${ }^{4} \mathrm{Karal}$, C. IX, s. 79; Tanin, 12 Ağustos 1908, s. 2.

${ }^{5}$ Güresin, 31 Mart Îsyant, s. 23. 
gelmektedir. Batılı büyük devletler, Osmanlı İmparatorluğu'ndan sağladıkları imtiyazların ve işletmekte oldukları sermayelerinin her ne olursa olsun tehlikeye düşmesini istemiyorlardı. Meşrutiyetin ilanını ilk sıralarda sempati ile karşılamaları da, bu hareketin er geç din, mezhep ve irk ayrılıkları ile bölünmüş olan Osmanlı topluluklarını birbirlerine düşüreceğini hesaba katmış olmalarından ileri gelmektedir. Bu amaçla harekete geçen batılı devletlerin, gerek basında ve gerekse Meclis içerisinde, kendi çıkarlarını savunan taraftarlar edinme yoluna girmekte tereddüt etmedikleri görülmektedir ${ }^{6}$. Özellikle, İngilizlerin 31 Mart Olayı sırasında oynadıkları rolü, dönemin genç bir gazetecisi olan Ahmet Emin (Yalman) hatıratında şöyle ifade etmektedir?: “... Derviş Vahdeti adlı Kıbrıslı sarhoş arzuhâlci, İngiliz Haberleşme Servisleri tarafından seçilmiş, İhtilâlci ajan olarak yetiştirilmiş, Volkan Gazetesi'ni ve İttihâd-ı Muhammedi Cemiyeti'ni kurmak, yürütmek ve ortalı̆̆ı ateşe vermek maksadl ile sahneye çıkarılmıştı."

31 Mart Olayı'nın oluşumunda Derviş Vahdeti ve O'nun çıkardığı “Volkan Gazetesi"nin yeri de son derece önemlidir. Derviş Vahdeti, 1870'de Kıbrıs'ta doğmuş ve büyümüştür. Asıl adı Derviş olan ve fakir bir aileye mensup Vahdeti, medrese okumuş ve 14 yaşında hafız olmuştur. Biraz Arapça ve Farsça öğrendiği için sırtına cüppe, başına sarık koyarak bir müddet hocalıkta bulunmuş, sonradan İngilizce öğrenip Kıbrıs'ta İngiliz Yüksek Komiserliği'nde vazife görmüştür. Kendi deyimiyle "Redingotlu ve eldivenli bir adam olarak kraliçe adına verilen balolara katılmıştır" ${ }^{8}$. Derviş Vahdeti'yi İngiliz idaresindeki memuriyet de tatmin etmemiş ve kısa bir süre sonra İstanbul'a gelmiștir. Amacı saraya girmek olan Vahdeti, nitekim Dahiliye Nazırı Memdûh Paşa vasıtasıyla "Göçmen Komisyonu"na atanmış ve Paşa'nın yalısında imamlık yapmaya başlamıştır. Fakat saraya girmek isteği, O'nu jurnalciliğe kadar götürmüş ve Memdûh Paşa'yı padişaha jurnallemiştir. Jurnali padişahtan öğrenen Dahiliye Nazırı, Vahdeti'yi Diyarbakır'a sürgüne göndermiştir. Diyarbakır'da, Vahdeti bir yandan İstanbul'a af dilekçeleri gönderirken, öte yandan sesinin güzel olması

\footnotetext{
${ }^{6}$ Karal, C. IX, s. 80-81.

7 Ahmet Emin Yalman, Yakın Tarihte Gördüklerim-Duyduklarım-Geçirdiklerim, C.I, İstanbul, Yenilik Basımevi, 1970, s. 95.

${ }^{8}$ Karal, C. IX., 1996, s. 75; Derviş Vahdeti, Padişah Abdülhamit'e yazdığı bir mektupta hayatını şöyle anlatmaktadır: "Padişahım ben nasıl doğdum, büyüdüm? Pederim, Pabuç̧u esnafindan Kıbrıslı Mahmut Ağa idi. Babam bütün gün çalışır, bir lokma ekmek parası kazanır, ufak bir evcikte hepimiz bir yorgan altında kısın soğuktan titrerdik. Gördün mü hayat nedir?... Dört yaşında mektebe girdim, beş yaşında Kur'ânı hatmettim. On dört yaşında hafız oldum. Bir miktar Arapça dil bilgisi, biraz Islam hukuku ögrendim. Nakşibendi tarikatına girdim. Yaşım yirmiyi buldu. Calıștım, biraz daha okudum. Ecnebi dil öğrenmek lazım geldiğini hissettim... Ancak başımdaki sarıkla ve Kur'ân'ı okumakla meşgulken din düşmanı bir kavmin lisanını nasıl öğrenebilirdim ki?... O sıralarda Istanbul'a geldim. Iki ay sonra Kıbrıs'a döndüm. Gözüm açıldı. Ötekinden berikinden biraz Ingilizce öğrendim. Kıyafet değiştirip hükümet memuru oldum. Kraliçe adına verilen balolarda redingotlu, eldivenli bir adam olarak göründüm. Yirmi beș sene hoca mesleğinde, hoca itikâdında, hoca kıyafetinde medrese köșelerinde bir Müslüman șimdi medeni... Her yüksek gördüğ̈̈m dereceye ayak bastıkça gözlerim daha ilerilere çevriliyordu..." Bkz., Güresin, 31 Mart İsyanı, s. 28-29.
} 
nedeniyle içki toplantılarında ud çalmakta ve şarkılar söylemektedir. Bir gün Kıbrıs'a gitmek için Diyarbakır'dan kaçmış, fakat Bektaşi babası kılığında Birecik'te yakalanarak tutuklanmıştır'. Meşrutiyetin ilan edilmesiyle serbest bırakılan Vahdeti, İstanbul'a tekrar gelmiş ve $\mathrm{O}$, zamanın özgürlük havası içinde bir şeyler yapmak, şeriatçılıktan faydalanarak ileriye fırlamak düşüncesini halâ korumaktadır. Gerçekten ümmetçilik ve şeriatçılık akımı bu dönemde hızla yayılmaktadır.

7 Ekim 1908'de Fatih Camisi'nde Kör Ali ve İsmail Hakkı adlarında iki hocanın harekete geçerek, "Ey ümmet-i Muhammet, din elden gidiyor! Sokaklarda alenen oruç yiyorlar, kadınlar yüzleri açık geziyorlar" şeklinde açıklamalarıyla halkı kışkırttıkları görülmektedir ${ }^{10}$. Bu iki yobaz hocanın arkasına takılan bilgisiz halkın Yıldız Sarayı'na kadar gidip Meşrutiyet hakkında gösteri yapmaları ile olayların daha da büyüdüğü görülecektir. Mabeyn Başkatibi Ali Cevat Bey, bu olaylar hakkındaki düşüncelerini şöyle açıklamaktadır ${ }^{11}$ :

"Eylülün yirmi dördünde (Ekim 1908 çarşamba) ve Ramazan-l Şerifin on birine müsâdif olan çarşamba günü saat on raddelerinde Efendimiz beni çă̆trarak 'Birçok Fatih hocaları Saray-ı Hümayûn pişgâhına gelmişler. Mutlak beni görmek istiyorlarmış. Baş-mabeyinci Nuri Paşa geldi, söyledi, bir kere de sen gör' buyurdular. Sarayın kapısı önüne çıktım; arakiyyenin üstüne bir sarık sarmış, gö̆ğ̈ü bağrı açık pejmürde kıyafetli, şaşı gözlü, meczub tavırlı bir adamın koltuğuna iki kişi girmiş ve etrafına da ellerinde bayraklar kırk elli kadar adam toplanmış, seyirci olarak bir çok halkın da bunlara takılarak gelmiş olduğunu gördüm. Ber-takrib bunların yanlarına sokuldum... Hoca Ali Efendi namında olan bu adam, meyhaneler kapanmall, resim çıkarmak men' olunmal, İslam kadınları sokaklara çıkamamalı, diyor idi... Zat-l şahâneleri Mabeyn dairesine teşrif buyurdular. Pencereyi açtım. Ali Efendi pencerenin önüne gelerek yüksek sesle 'Padişahım çoban isteriz, çobansız sürü olmaz. Şeriat emrediyor, meyhaneler kapanmalı, İslam kadınları açık, saçık sokaklarda gezmemeli, resim çıkartılmamal, tiyatrolar kapanmalt... Korkma, tecelliyat var. Evliya perde altında tecelli ediyor."

Bütün bu olaylar üzerine II. Abdülhamit, "icap eden emir verilir. Muktezây-l şeriat icra olunur. Müsterih olun hoca efendi" sözleriyle şeriatçılara pek yüz vermemekle birlikte onları ümitlendirecek sözler söylemiştir. Bu davranışı daha sonraki günlerde kendisi için hiç de iyi olmayacaktır $^{12}$. Kör Ali Olayı çok güȩ bastırılmış ve elebaşı hocalar (Kör Ali

\footnotetext{
${ }^{9}$ Güresin, 31 Mart Isyant, s. 29. 130.

${ }^{10}$ Sina Akşin, Jön Türkler ve İttihat Terakki, 2. B., Ankara, İmge Kitabevi, 1998, s.129-

"Bayur, Türk Inkılabı Tarihi, C. I, s. 125-126; Faik Reşit Unat, İkinci Meşrutiyetin Ilanı ve Otuz. Bir Mart Hâdisesi, II. Abdülhamid'in Son Mabeyn Başkâtibi Ali Cevat Bey'in Fezlekesi, 2. B., Ankara, TTK, 1985, s. 15-16.

${ }^{12}$ Bayur, C. I, Ks. II, s. 126.
} 
ve İsmail Hakk1), bu şahlanı̧̧ ve isyan denemesi sonunda asılarak cezalandırılmışlardır.

Bu hareketi birkaç gün sonra bir ikincisi takip etmiş, Beşiktaş'ta Ekim ortasında bir Rum bahçıvana kaçan, Müslüman bir kadın yüzünden olaylar tekrar başlamıştır. Birbirlerini seven gençlerden Bedriye'nin Todori'ye kaçması üzerine, taassubu kabaran ve galeyana gelen halk ayaklanmıştır. Polis karakoluna götürülen genci, karakolu basarak polisin gözü önünde linç ederek öldürmüşlerdir. Öldürme sebebi yine aynıdır ${ }^{13}$ : "Şeriat mahvoluyor! Zira ırz ve namus gâvurların ayakları altına alınmıştır!"

Bu arada Kör Ali ve Beşiktaş Olayları'nı yakından takip eden kurnaz Derviş Vahdeti'nin, gazete çıkarmak için saraya başvurup para istemesi de, irticanın Abdülhamit'ten ümit kesmemiş olduğunu göstermesi açısından son derece önemlidir ${ }^{14}$. Gerçekten bütün bu gelişmeler incelendiği zaman, açık olarak görülmektedir ki, amaç, Meşrutiyet aleyhinde gelişen bu ortamı şeriatçılığa kanalize etmek ve şeriatçılığı örgütleyerek siyasi bir topluluk haline sokabilmektir.

1908 devriminden önce ordu içinde gelişen siyasetçilik, II. Meşrutiyet'ten sonra bir süre durulmuş, fakat subaylar çoğunlukla İttihat ve Terakki'nin destekçiliğini bırakmamışlardı. Ne var ki, çeşitli propagandalarla saray ve softa takımının yavaş yavaş silahlı kuvvetlerin içine girmeye başlayacakları görülecektir. Fakat, Selanik'teki 3 ncü Ordu ile Trakya'daki 2 nci Ordunun fikri dayanışması; İstanbul ve Erzurum'da gerçekleşmeyecektir ${ }^{15}$. Ekim 1908'den itibaren ordu içinde çeşitli dini propagandaların etkisiyle "alayll" ve "mektepli" subaylar meselesi ortaya çıkmıştır. Gelişmiş harp teknolojisinin bilgiye dayanması, bu bilginin erlere aktarılması ve dolayısıyla ordunun gençleştirilmesi gerekiyordu. Bilindiği üzere ordu içerisinde askerlikten yetişme subayların yanı sıra, okullardan yetişen genç subaylar da bulunuyordu. Yeni yönetimin, alaylı subayları kısa bir süre sonra tasfiye edeceği söylentileri, ordu içerisinde hızla yayılmaya başlamış $^{16}$ ve bu söylentilerden etkilenen alaylı subayların, mektepli subaylarla olan ilişkileri her geçen gün biraz daha bozulmuştur. Bununla da yetinmeyen alaylı subayların, bu düzeni yıkıcı bazı propaganda çalışmalarına girişmesi gibi olaylar ${ }^{17}$, çok yakında çıkacak olan ayaklanmanın birer habercisi olmuştur.

31 Mart Olayı öncesi meydana gelen ilk ayaklanma, Ekim 1908 sonlarında İstanbul-Taşkışla'da gerçekleşmiş̧tir. Askerlik sürelerini doldurarak terhis olmayı bekleyen 87 eratın, askerlik sürelerinin tekrar

${ }^{13}$ Tunaya, İslamcılık Akımı, s. 127; Güresin, 31 Mart İsyanı, s. 30; Bayur, Türk Inkılabl Tarihi, C. I, Ks. II, s. 125.

${ }^{14}$ Bayur, s. 126.

${ }^{15}$ Güresin, 31 Mart isyant, s. 24

${ }^{16}$ Bayur, Türk inkılabı Tarihi, C. I, Ks. II, s. 142.

${ }_{17}$ Bu söylentiler üzerine, alaylı subaylar arasında bir takım toplantılar yapılmış ve bu toplantılara öncülük eden I. Süvari Tümeni Komutanı Refik Paşa, altı ay hapse mahkum olmuştur. Bkz., Bayur, Türk Inkılabı Tarihi, C. I, Ks. II, s. 141. 
uzatılması ve Hicaz'da görevlendirilmesi, hoşnutsuzluğun artmasına neden olmuştur. Başlarında çavuşları olmak üzere Taşkışla'da ayaklanan erler, kendilerini yakalamak isteyen hükümet güçlerine karşı direnmişler ve yapılan çarpışmalarda birkaç ölü ve yaralı vermişlerdir. Nitekim bu isyan hareketi, onlara karşı Selanik'ten getirilmiş ve aynı kışlada kalan Avcı taburları ile bastırılmıştıิ ${ }^{18}$.

Bu olaydan sonra ordu içerisinde disiplini sağlamak amacıyla bir takım emirlerin yayınlandığı görülmektedir. Özellikle subayların siyasetle uğraşmamaları ve tiyatrolarda oyunculuk etmemeleri gibi ordu disiplinini bozan ve erleri de saygısız yaptığına inanılan emirlerin çokluğu dikkat çekicidir. Fakat alınan bu gibi önlemler, ordu içindeki gergin ortamı daha da arttırmış ve Aralık 1908 başlarında ikinci bir ayaklanmanın zeminini hazırlamıştır. Bir tiyatro oyununda oyunun erlere yasak edilmesi, tartışmaları beraberinde getirmiş ve erlerin "bize yasaksa subaylara da yasak olmalıdır" diyerek tiyatroyu basması, şiddetli çarpışmalara neden olmuştur. Uzun mücadelelerden sonra bastırılan bu ayaklanma, ordudaki huzursuzluğu göstermesi açısından son derece önemlidir ${ }^{19}$.

Ordunun düzensizliğine paralel olarak askeri kesimde başlayan bu ayaklanmalara, 23 Ocak 1909'da Harp Okulu öğrencileri de katılmıștır. Okul Nizamnamesi'nin aşırı sertliğini ve yabancı dil öğrenmekte güçlük çektiklerini dile getiren öğrencilerin ayaklanması, hükümeti bir hayli uğraştırmıştır. Ayaklanmanın bastırılmasıyla birlikte, yapılan soruşturmalarda olaylara karışan 60 öğrenci okuldan kovulmuş ve hapsedilmiştir. Kalanlara ise her emre uyacakları yolunda yemin ettirilmiştir ${ }^{20}$. Ordu içerisinde meydana gelen bu gibi olaylar, İttihatçılara duyulan tepkinin daha da artmasına neden olacaktır.

Alınan tüm önlemlere rağmen, ordu içerisinde meydana gelen bu tür olaylara son vermek amaciyla Harbiye Nezareti'nin, 21 Şubat 1909'da ikinci bir yazılı emir yayınladığı görülmektedir $\mathrm{Ad}_{1}$ geçen emir, ordu mensuplarının politika ile uğraşmalarını, siyasal cemiyetlere girmelerini ve siyasi toplantılarda söylevlerde bulunmalarını yasaklamıştır ${ }^{21}$. Fakat, alınan bütün bu olumlu kararların, hem geç kaldığı hem de içtenlikle yürütülemediği, kısa bir süre sonra çıkacak olan 31 Mart Olayı'nda açık bir şekilde görülecektir.

Bilindiği üzere Abdülhamit'in koruyucu birlikleri arasında Söğüt bölgesinden gelme Türklerin yanı sıra, birkaç bin Arnavut ve Arap eri vardı. Bunlar ayrı birliklerde bulunur ve aralarına Türk erleri katılamazdı. Bunun nedeni ise, İstanbul halkının düşünce ve duygularına yabancı kalan ve hatta

\footnotetext{
${ }^{18}$ A.g.e., s. 141. II, s. 142 .

${ }^{19}$ Olay Kosova Vilâyeti'nin Köprülü kentinde meydana gelmiştir. Bkz., Bayur, C. I, Ks.

${ }^{20}$ Çağlar Kırçak,, Meşrutiyetten Günümüze Gericilik, 2. B., Ankara, İmge Kitabevi, 1994, s. 52.

${ }^{21}$ Bayur, C. I, Ks. II, s. 183.
} 
az veya hiç Türkçe bilmeyen erlerle korunmak, II. Abdülhamit'in kendisini daha çok güvende hissetmesini sağlıyordu. Mart 1909 sonlarında askerlik süresi bitmiş olan bir kısım Arnavut ve Arap erlerinin yerine Türk erleri verilince, Arnavutların bunları kabul etmediğini ve döverek dışarı attığını görmekteyiz. Bu olay çeşitli tedbirler alınarak bastırılmış ve saray etrafındaki kışlalara da "AvCl Taburları" yerleştirilmiştir ${ }^{22}$.

Burada üzerinde durulması gereken önemli konu, bütün bu olaylarda hep Selanik'ten getirilmiş olan avcı taburlarının ayaklanan birliklere karşı kullanılmış olması ve dolayısıyla bu durum Birinci Ordu içerisinde avcı taburlarına karşı genel bir düşmanlık duygusunun doğmasına yol açmıştı.

Nisan 1909'da ordu içerisinde, talimlerin çokluğu yüzünden namaz kılmaya ve hamama gitmeye vakit kalmadığı yönünde çeşitli söylentilerin çıkmaya başladığı görülmektedir. Özellikle Üçüncü Ordu tarafından hazırlanan ve son derece yoğun olan bu eğitim programı, alaylı subayların tepkisini çekmiști. Bu durumdan yararlanmak isteyen bazı alaylı subaylar ile ilmiye sınıfına bağlı din adamları, ordu içinde ibadet ve çeşitli bölücü propagandalarına hız vermişlerdir. "Nasihat" adı altında geceleri verilen vaazlar nedeniyle askerlerin gece tatbikatlarına çıkarılmamaya başlanması üzerine özellikle Hassa Ordusu tarafından günlük emirler çıkarılmıştır. Bu emirlerde ise, "namaz kılmak bahanesiyle askerin talim ve terbiyeden geri kalmamalarına meydan verilmemesi" istenmektedir ${ }^{23}$. Hassa Ordusu için çıkarılan bu günlük emir, ordu içindeki ilmiye sınıfına bağlı din adamları tarafından istismar edilerek, " kafirler idaresinin ordudan namazı kaldıracakları ve artık erlerin namaz kılamayacakları" şeklinde propaganda malzemesine dönüştürülmüştür. Ordu içerisinde başlayan bu bölücü propaganda çalışmaların, kısa bir süre sonra İstanbul'un en ücra köşelerine kadar yayıldığı görülmektedir ${ }^{24}$.

31 Mart'a etki yapan propagandalardan biri de şapka (serpuş) meselesidir. O günlerde askeri kıyafetlerde bir takım düzenlemelerin yapılması gündeme gelmiş ve asker şapkalarının değiştirilmesi meselesi, Meşrutiyet muhaliflerini ve dini ulemayı harekete geçirmiştir. Yabancı müşavirlerin istekleri doğrultusunda hazırlanan kıyafet değişiklikleri ve özellikle başlıkların güneşlikli olması önerileri çok iyi birer propaganda malzemesine dönüştürülmüştür. Namazın kaldırılması gibi serpuş meselesi de, bu taassup kesim tarafından çok iyi bir şekilde kullanılmış ve sonradan polis romanlarına dönüşecek kadar çok hikâyeler uydurulmuştur ${ }^{25}$.

${ }^{22}$ Olayların başlamasına neden olan Arnavut ve Arap taburları, alınan önlemler neticesinde önce Taşkışla'ya, daha sonra Arnavutlar Selanik'e ve Araplar da Şam'a gönderilmiştir. Bkz., Bayur, Türk Inkılâbı Tarihi, C. I, Ks. II, s. 141.

${ }^{23}$ Güresin, 31 Mart Ísyant, s. 25; Bayur, C. I, Ks. II, s. 142

2431 Mart Olayı'nı İttihat ve Terakki Partisi'nin düzenlediğini iddia edenler, namaz sorununu, sonradan başka şekillere sokarak, emrin ordu içinde isyan çıkarmak için hazırlandığını ve hocaların da İttihat ve Terakki ajanları olduğunu söyleyeceklerdir. Onlara göre İttihaţ̧ıların amacı, Abdülhamit'i devirmekti. Bkz. Güresin, s. 25.

${ }_{25}$ Güresin, 31 Mart İsyanı, s. 28-29. 
İstanbul'da asker arasında gizli olarak yürütülen ve hükümetin, subayların kafir oldukları, şeriatı kaldıracakları ve kendilerini de kâfir yapacakları gibi propagandalar, tüm hızıyla devam etmektedir. Bu propagandaların odak noktası, Selanik'ten gelen ve Meşrutiyetin direği sanılan İttihat ve Terakki Cemiyeti'nin en çok güvendiği, avcı taburlarının erleri olmuştur. Erlere karşı yapılan bu olumsuz propagandalara çeşitli tehditlerin de eklendiği görülmektedir. Özellikle avc1 erlerine, diğer asker kardeşlerine karşı cephe aldıkları, onları ezdikleri ve ülkenin kafirleştirilmesine alet oldukları söylenmekte ve kısa zaman içinde askerhalk tarafından ezilecekleri tehdidi ileri sürülmektedir ${ }^{26}$.

31 Mart Olayı'na doğru gidişte etkili olan bir başka olay ise, o zamana kadar askere alınmayan ve "Talebe-i Ulûm" adi verilen medrese öğrencilerinin de askere alınmalarını içeren yasa tasarısının gündeme gelmesidir. Bu tasarıya karşı medrese öğrencileri ve din adamları ayaklanmışlar, "dinimiz elden gidiyor" propagandasını daha da yoğunlaştırmışlardır ${ }^{27}$.

Bütün bu siyasal hava, Mart ayının sonuna doğru kararmaya, fırtına alâmetleri belirmeye başlamıştı. İttihat ve Terakki, bir iktidar partisi olarak iç ve dış sorunlar arasında sıkışmış ve otoriter bir yola sapmıștı. Otuz yıllık bir istibdat rejiminden henüz kurtulduklarını sananların şaşkınlığı, yerini sert bir muhalefete bırakmıştır ${ }^{28}$. İttihat ve Terakki, kurtarıcı bir organ olarak önce orduda idareci bazında geniş bir tasfiye hareketine girişmiş, ordudan önemli sayıda alaylı subaylar atılmış ve birçok memur açıkta kalmıştır ${ }^{29}$. Bunun yanı sıra İttihatçı fedâilerin muhalefet saflarındaki gazetecilere saldırıları genel havayı altüst etmiş ve İttihatçıların dikta yoluna gidişlerini bu gibi olaylar açıkça göstermektedir ${ }^{30}$.

Bu gergin ortamda 6/7 Nisan 1909 gecesi, İttihat ve Terakki Cemiyeti'ni en çok eleştiren gazetelerden birisi olan Serbesti gazetesinin başyazarı Hasan Fehmi Bey’in, Galata köprüsü üzerinde öldürülmesi, bardağı taşıran son damla olmuştur ${ }^{31}$. Bu cinayet, ertesi gün muhalefet

${ }^{26}$ Bayur, Türk Inkılabı Tarihi, C. I, Ks. II, s.182.

${ }^{27}$ Bu tasarı ile medrese ögrencilerinin de diğer gençler gibi askere alınması son derece doğru ve gereklidir. Ancak bu tasarının, dini bahane olarak kullanan propagandaların çok yoğun olduğu bir dönemde gündeme getirilmesi, yani zamanlaması çok yanlıştı. Ayrıntılı bilgi için bkz., Bayur, C. I, Ks. II, s. 183.

${ }_{28}$ Zafer Tarık Tunaya, Hürriyetin Ilanı Ikinci Mesrutiyetin Siyasi Hayatına Bakıslar, 1. B., İstanbul, Bilgi Üniversitesi Yayınları, 2004, s. 31-52.

${ }^{29}$ Mustafa Baydar, 31 Mart Vak'asl, İstanbul, Anıl Matbaası, 1955, s. 6-10.

${ }^{30}$ Tunaya, islamcilık Akımı, s. 123.

${ }^{31}$ Serbesti gazetesi Başyazarı Hasan Fehmi Bey, 6 Nisan gecesi Galata Köprüsü'nde Kaymakam Şakir Bey'le birlikte Karaköy'den Eminönü'ne geçerken tam ortada bir el silah patlamış, önce Şakir Bey yaralanmıştır. Bunu üç el daha patlama izlemiş ve Hasan Fehmi Bey yere düşmüştür. Hafif yaralı Şakir Bey yardım istemek için Eminönü'ne doğru koşmuş ve yolda bir polise rastlamıştır. Polis Şakir Bey'i katil zannederek karakola götürmüs ve durumu anlatıncaya kadar katil veya katiller kaçmışlardır. Ayrıntılı bilgi için bkz., Güresin, 31 Mart İsyanı, s. 39-40; Akşin, Ana çizgileriyle..., s. 49. 
gazetelerini ve büyük bir kitleyi harekete geçirmiştir ${ }^{32}$. Olayın fazla üzerine gidilmemesi ve katillerin bulunamaması üzerine, olayla ilgili olarak çeşitli iddiaların ortaya atıldı ̆̆ı görülmektedir. Öldürenin İttihatçılardan Abdülkadir olduğu, ölüm emrinin İttihat ve Terakki Cemiyeti'nce verildiği ve Hükümetin de Cemiyete bağımlı olması nedeniyle olayla ilgilenmediği gibi sözler, ortamı büsbütün gerginleştirmiştir. 7 Nisan 1909'da İstanbul'da öğrencilerin de katılımlarıyla büyük gösteriler başlamış ve hükümetten adalet istenmiştir. Ayrıca bir hafta boyunca İstanbul gazeteleri arasında da çetin tartışmalar yaşanmıştır ${ }^{33}$.

Muhalefetin şiddetini ve şiddetin gerici ayaklanma ortamının yaratılmasına nasıl fırsat verdiğini gösterebilmek için o günlerin gazetelerine göz atmakta yarar vardır. Serbesti gazetesi yayınladığı protesto mektubunda, olayın İstanbul'un en kalabalık yerinde meydana geldiğini söyleyerek, yüksek öğrenim gençliğinin Millet Meclisi'ne giderek Başkan Ahmet Rıza Bey'i görmek istediklerini belirtmiş, oysa Başkanın Jandarma çă̆ırıp pencereden de öğrencileri galeyana getirecek sözler söylediğini yazmakta ve Ahmet Rıza Bey'i kınamaktadır ${ }^{34}$. İkdam gazetesi de, bu korkunç cinayeti kınamakta ve cenaze töreni hakkında şöyle bilgiler vermektedir ${ }^{35}$ :

“... Gerçek Hürriyetin vatanımıza henüz dahil olmadığı, siyasi esaretin bütün çirkinlikleriyle yerinde durduğunu, bütün fecati ile ispat eden dün gece ki vahşi cinayet, ertesi sabah biçare halkımızın temiz yüzünde büyük matemin kaderini husule getirdi... Serbesti idarehanesinin önü, Hürriyet Şehidi Hasan Fehmi Bey'e son veda geçidini yapmak ve onu bu perişan duruma sokan gizli kuvvete lanet etmek için akın akın gelen ahâli ile dolu bulunuyordu."

O günlerin bir başka gazetesi "Mizan" da hükümete karşı sözlü saldırıların dozunu biraz daha artırmış ve "... miskinlik içindeki böyle bir hükümete biz Osmanlı Hükümeti adını veremeyiz. Kahraman ordular ve asker, Allah'ın gayretiyle hürriyeti getirdiler. Hürriyeti meçhul bir çete, firsatı ganimet bilerek Yıldı'dan istibdat dolabını çaldı. Bab-ı Âli'nin böyle bir çeteye yataklık ettiği tahakkuk ederse, böyle bir Bab-ı Âli'yi biz üzerimize hakim değil, ayă̆ımıza toz olarak bile kabul edemeyiz. Artık kâfirdir, fazlasına milletin tahammülü kalmamıştır" gibi ağır sözlere yer vermektedir ${ }^{36}$.

Yine 31 Mart'a yaklaşan günlerde Volkan gazetesinin, iktidar partisi olan İttihat ve Terakki Fırkası'nın almış olduğu tedbirlere karşı, çok sert bir hücuma geçtiği görülmektedir. 10 Kasım 1908'de “Volkan Gazetesi”ni

\footnotetext{
${ }^{32}$ Tunaya, İslamcılık Akımı, s. 123; Bayur, Türk Inkılabı Tarihi, C. I, Ks. II, s. 183.

${ }^{33}$ Katil zanlısı olarak anılan Abdülkadir, İttihat ve Terakki Cemiyeti'ne mensup olup daha sonralan Mustafa Kemal Paşa'ya karşı hazırlanan İzmir suikastında ön plana çıkmış ve idamla cezalandırılmıștır. Bkz., Bayur, C. I, Ks. II, s. 183.

${ }^{34}$ Güresin, 31 Mart Isyanl, s. 41; Serbesti Gazetesi, 27 Mart 1325 (9 Nisan 1909), s. 1.

${ }^{35}$ Ecvet Güresin, 31 Mart Ísyani, İstanbul, Habora Kitabevi, 1969, s. 40-41;

${ }^{36}$ Íkdam Gazetesi, 27 Mart 1325 (9 Nisan 1909), s. 2; Güresin, 31 Mart İsyanı, s. 41; Mizan Gazetesi, 27 Mart 1325 (9 Nisan 1909), s. 2.
} 
çıkaran Vahdeti'nin yazıları, birer hutbe niteliğinde, bol feryatlı olup, halka oldukça etki ediyordu ${ }^{37}$. Sayın Akşin, Volkan gazetesinin temel niteliklerini şöyle belirtmektedir ${ }^{38}$ :

"İslamiyetçi nitelik, hürriyetçi ve Kanun-u Esasî düzeninden yana olmak ve insaniyetçi ve medeniyetçi nitelik... Vahdeti evrensel barıştan, üfürükşülere karşı doktordan, tıpta yeni buluşlardan yanadir. Vahdeti yazılarında Dreyfus, Zola, Darwin'i anacak kadar, Batı bilginlerinden haberlidir... Fedâkârancı nitelĭğe sahip olup eski sürgün ve kaçkınları korur. Dervis başta Ahmet Rıza olmak üzere, ITC. sivil ileri gelenlerinin şiddetle aleyhindedir. Buna karşıllk Sabahattin Bey'i ve onun düşüncelerini, Kâmil Paşa'yl tutmaktadır. Bu tutuma paralel olarak da İngiliz taraftarlığt söz konusudur. Derviş'e göre güdülecek en doğru siyaset İngiliz siyasetidir."

Mabeyn Başkâtibi Ali Cevat Bey ise, Derviş Vahdeti ve gazetesi hakkında şu bilgileri vermektedir ${ }^{39}$ :

"Kesin tarihini pek iyi hatırlayamadığım bir gün, orta boylu, kısa sakall, al yanakl, dar ve açık renk pantolonlu bir adam yanıma gelerek isminin Derviş Vahdeti olduğunu ve bir gazete çıkarmak için tahsisat istediğini söyledi. Nitekim, o güne kadar bu şahsı hiç görmemiş olmama rağmen, kendisinin serseri hayatını, daha evvel mabeyn kâtibi iken yazılmıs tahrirattan bildiğimden, artık o devirde tahsisat ile gazete çıkarmanin ne memlekete, ne saltanata ve devlete faydalı olmayacağımı, buna imkân kalmadı̆̆ını anlattım, gitti. Daha sonra 31 Mart hadisesinde rol oynayan Volkan gazetesini ve bu hadisenin asl mürettibi olan fesat Cemiyetini, hangi para ile tutmus, bilmiyorum."

Derviş Vahdeti, kendi sözleriyle de ifade ettiği gibi fakir bir ailedendi ve mal edinebilecek bir kariyere de sahip değildi. Dolayısıyla Vahdeti'nin, Volkan gazetesini nasıl çıkardığı ve sözü edilen "İttihâd-ı Muhammedi Fırkası"nı nasıl kurduğu hakkında çok fazla bi gi bulunmamaktadır. Fakat Derviş Vahdeti'nin bu gazeteyi çıkarmaya başlamasının, Sadrazam Kâmil Paşa'nın İttihat ve Terakki ile bozuştuğu; İttihe.d-1 Muhammedi Fırkası'nı kurmasının da yine Kıbrıslı Kâmil Paşa'nın İttihat ve Terakki'ye karşı komplo kurmaya giriştiği zamana rastlaması, sın derece dikkat çekilmesi gereken olaylardır ${ }^{40}$.

Derviş Vahdeti, Kıbrıslı Kâmil Paşa'dan yana tavrını sürdürmüş ve Paşa'nın Anayasa kurallarına aykırı olarak: düşürüldüğünü Volkan

${ }^{37}$ Tevfik Çandar, Itttihat-Terakki, İstanbul, İletişim Yayınları, 1991, s. 48.

${ }^{38}$ Sina Akşin, 31 Mart Olayl, Ankara, AÜ. SBF. Yayınları, 1970, s. 35; Unat, İkinci Meşrutiyet'in Ilanı ve Otuz Bir Mart Hâdisesi, II. Abdülhamid'in Son Mabeyn Başkâtibi Ali Cevat Bey'in Fezlekesi, s. 45-46.

${ }^{39}$ Unat, s. 45-46. s. $75-76$.

${ }^{40}$ Karal, Osmanlı Tarihi, İkinci Meşrutiyet ve Birinci Dünya Savaşı (1908-1918), C. IX, 
gazetesinde ${ }^{41}$, "Kâmil'in namusu ikmal edilecektir; ikmal" şeklinde dile getirerek savunması, yukarıda açıklanan bilgileri doğrulamaktadır. Vahdeti'nin, bu namusu tamamlama sorununda bütün muhalif gazeteleri, İttihatçılara karşı ortak hareket etme konusunda birliğe çağırdığı görülecektir. Bunun yanı sıra Vahdeti, İttihatçıları devirmek için gazeteciğin gücünü de yeterli görmemiş ve daha yıkıcı, daha hızlı sonuç alınabilecek bir silahı aramaya başlamıştır. Uzun bir süre aranan ve son derece etkili olan bu silah ise, "din" olmuştur. Vahdetinin bu düşüncesi, 16 Mart 1909 tarihli Volkan gazetesinde yayınlanan bir beyanname ile şöyle açılanmaktadır ${ }^{42}$ :

“Biz ki Muhammedi'yiz, Şer'-i Şerif dairesinde hareket etmek mecburiyetindeyiz. Bu selâhiyetimize de hiçbir şahs-ı mânevi karışmaz ve karışamaz. Bulunduğumuz şu asr-l medeniyette, hiçbir fert diğerinin esiri olamaz. İşte bu esaretten millet-i muazzama-i Íslamiyeyi, tahlise, yani bil-cümle Müslüman'ın tabi bulunduklarl devletler idaresinde, tabi bulunduklarl kavânin dairesinde hareket ederek terakkilerine çalışmaktadır."

Bu beyannamede, sömürgelerdeki Müslümanların sömürgeci devletlere itaat etmeleri telkin edilmekte ve Osmanlı Müslümanları için "şeriat isteriz" yani "gâvurdan alınmış kanun istemeyiz" iddialarıyla halkın kışkırtıldığ 1 açık olarak görülmektedir ${ }^{43}$. Bu arada Vahdeti tarafindan kurulmuş İttihâd-1 Muhammedi Cemiyeti örgütlenmesini tamamlamış ve Cemiyetin yayın organı olan Volkan'ın peşinden tüm muhalif basın harekete geçmiş ve bir muhalefet partisi olan "Ahrar Fırkası" da artık İttihâd-1 Muhammedi Cemiyeti'ni desteklemektedir. Bu karışık ortamda alaylı subaylar ve yeni düzenlemelerle işten çıkarılan memurlar hakkında tahrik edici yazılar yazarak, orduyu ayaklandırmaya yönlendiren Volkan gazetesi" hiçbir zaman Avrupa'dan Frenkleşerek dönmüs dört-beş tane sarhoş için askerlik etmemelidir... Zira bu kişiler vatanperver değildir. İşte parola: Asker! Millet sizden bu dakikada hizmet bekliyor. Düşününüz, inanınız, yapınız" gibi sözlerle ortamı daha da gerginleştirmekte idi. Gazetede, Hasan Fehmi Bey'in öldürülmesiyle artık isyan hakkının meşrulaştığı düşüncesi şöyle ifade edilmektedir ${ }^{45}$ : "Hükümet, ya şehid-i hürriyet Hasan Fehmi Bey'in katilini bulmall, yahut malum olan beş kişiyi vatan haricine çıkarmalı. Bu ikiden madâsı milletin galeyanını teskin edemez... İşte mezâlim, işte Meşrutiyet. Çaresi ise umumi bir icmâ-ı ümmet (fikirlerin uzlaştı̆̆ dinsel yorum).".

${ }^{41}$ A.g.e., s. 76; Volkan Gazetesi, No: 49, 5 Şubat 1324, s. 1.

${ }^{42}$ Volkan Gazetesi, Beyanname Sureti, 16 Mart 1909, s. 2; Bayur, Türk Inkılabı Tarihi, C. I, Ks. II, s. 135-136.

${ }^{43}$ Bayur, Türk Inkllabı Tarihi, C. I, Ks. II, s. 136

${ }^{44}$ Volkan Gazetesi, "Ittihat ve Terakki Cemiyeti", 26 Mart 1325, No: 81, s. 1.

${ }^{45}$ Tunaya, Islamcilık Akımı, s. 125; Volkan Gazetesi, "Teskin-i Heyacan Muhal-1 Baş makale", 1325, No. 102; Derviş Vahdeti, "Halife-i İslam Abdülhamit Hazretlerine açık Mektup", 1325, No. 104, s. 1. 
Muhalefet gazetelerinin gittikçe sertleşen hücumundan çok iyi yararlanmayı bilen Derviş Vahdeti, 28 Mart tarihli Volkan gazetesinde şu açıklamayı yapmaktadır ${ }^{46}$ :

“Hasan! Ey Fatma'nın oğluyla ayn isimde olan Hasan! Onunla senin aranda büyük bir münasebet buluyorum. $O$, anadan babadan mahrum olarak şehit edildi. Sen de onun gibi öksüz, sen de garip olarak şehit edildin. O yezidilere muhalif idi. Sen de aynı firkaya muarız idin. Yezidiler İslam hükümetini zapt etmişlerdi. Bunlar da Osmanl Hükümeti'ni zapt etmek istemişlerdir. $O$, 'Allah'ın emri bize biâttır' diyordu, sen de 'Anayasa şeriattır. Ona itaat şarttır' diyordun. Nedir aranizdaki münasebet Hasan! Sen o musun, yoksa o sende mi? O'na İslam alemi kan ağladı. Sana da bütün insaniyet ağllyor. Git Hasan, Ebu-Tâlib'in oğluna benden selam söyle! Vahdeti de geliyor de ve kabulünü rica et!"

30 Mart 1325 günü Derviş Vahdeti yine ${ }^{47}$, “... O istibdata ki şeref sokağının pis, murdar elleriyle icra ediliyor, boyun eğersek kansız bir millet olduğumuza dünya kâni olacak, milli hislerimiz hakarete uğrayacak. Eğmeyelim, bu cinayetlere kat'iyen boyun eğmeyelim. Bunun çaresi ümmetin toplanmasıdır" şeklindeki yazılarının şiddetini daha da artırmıştır. Artık Derviş Vahdeti'nin, “ya hürriyet şehidi Hasan Fehmi Bey'in katili bulunmall, yahut malum olan beş kişiyi, (Ittihatçıları) vatan haricine çıkarmalı. Bu ikisinden başkası milletin galeyanını durduramaz" şeklinde konuşmalarından da anlaşılacağı üzere, kamuoyu ve askerler arasında yapılan propagandaların artık olgunlaştığı görülmektedir ${ }^{48}$.

Bilindiği üzere Rumeli'den İstanbul'a getirilmiş olan en seçkin birlikler 2., 3., 4., Avcı Taburları olup, 4 ncü Avcı Taburu'da Taşkışla'ya yerleştirilmişti ${ }^{49}$. 12-13 Nisan 1909 gece yarısı (Rumi takvimle 30 Mart'ı 31 'e bağlayan gece) Meşrutiyetin ve özgürlüğün koruyucusu olan Taşkışla'daki bu avcı taburu, başlarında çavuşları olmak üzere ayaklanmış ve kışladaki komutayı ellerine geçirerek bazı subayları hapsetmişlerdir ${ }^{50}$. Bu ayaklanmanın önderliğini ise, Hamdi Yaşar Çavuş, Bölük Yazıcısı Mehmet ve Tüfekçi Ustası Arif gibi bazı cahil askerler yapmaktadır. Sabaha doğru kışlanın kapıları açılmış ve subaysız askerler Divan Yolu'ndan geçerek Ayasofya Meydanı'na ilerlemeye başlamışlard1 ${ }^{51}$. Ne tesadüftür ki tabur harekete geçtiği zaman kışlanın önünde ellerinde yeşil bayraklar bulunan bir takım sarıklı hocalar, "Ey kahramanlar, şeriat elden gidiyor, ne duruyorsunuz?" diye pencerelere seslenerek isyanı teşvik etmişlerdir. Taşkışla'dan öteki kışlalara da yayılan isyan, kısa süre içinde büyümüş,

${ }^{46}$ Güresin, 31 Mart İsyant, s. 42; Volkan Gazetesi, "Derviş Vahdeti'nin Nutku”, 28 Mart 1325, s. 1 .

${ }_{47}^{4}$ A.g.e., s. 42; Volkan Gazetesi, 30 Mart 1325, s. 2.

${ }^{48}$ Güresin, 31 Mart İsyant, s. 42.

${ }^{49}$ A.g.e., s. 43; Tunaya, Islamcilik Akımı, s. 127-128.

${ }^{50}$ Bayur, Türk Inkılabı Tarihi, C. I, Ks. II, s. 184; Akşin, s. 50.

${ }^{51}$ Kırçak, Meşrutiyetten Günümüze Gericilik, s. 54. 
askerler "şeriat isteriz, padişahım çok yaşa" sözleriyle ve önlerinde hocalar olduğu halde Ayasofya-Sultanahmet Meydanı'nda toplanmıştır ${ }^{52}$.

Sayıları 5-6 bini bulan askerlerin meydanda toplanmasıyla birlikte yüzlerce hoca ve medrese öğrencileri, sırtlarında cübbeleri, başlarında sarıkları olduğu halde meydana gelmeye başlamışlar ve isyancılar tarafından tekbirlerle karşılanarak kendileri için ayrılan yerlere oturtulmuşlardır. Asker ve hocaların sandalye üzerinde yaptığı konuşmalar, daha çok dinin elden gittiği ve şeriatın hâkim olması gerektiği şeklindedir. Ayrıca yapılan bütün konuşmalarda, mektepli subayların orduyu frenkleştirmeye çalıştıkları, bütün bunların İttihat ve Terakki Cemiyeti'nin başı altından çıktığı, din hükümlerinin ayaklar altına alındığı sıklıkla ifade edilmektedir ${ }^{53}$.

İlk bakışta basit ve dağınık bir görüntü çizen bu isyanın hazırlık planları, haftalarca önce yapılmış ve isyancıların hareket tarzları belirlenmişti. İsyanın daha önceden planlandığını gösteren en önemli gelişme ise, özellikle kadro dışı bırakılmış bazı subayların, sivil elbise ile isyanı yönetmeleri, isyancıların her ihtimali göz önüne alarak yabancı elçiliklerin kapılarına nöbetçiler dikmesi ve Hıristiyanlara dokunulmayacağına dair teminatlar vermiş olmaları şeklinde özetlenebilir ${ }^{54}$.

Ayasofya Meydanı'na yakın bir mesafede bulunan Millet Meclisi binası çevresindeki kalabalığın saatler ilerledikçe artması üzerine, isyancılar klasik yeniçeri ayaklanmalarında olduğu gibi, Şeyhülislam Ziyaettin Efendi'yi Ayasofya Meydanı'na getirerek, isteklerinin hükümete ulaştırılmasında aracılık yapmasını istemişlerdir ${ }^{55}$. Bu arada Mebûsan Meclisi binasını kuşatan isyancıların siyasi istekleri şunlardı ${ }^{56}$ :

“Ahkâm-l Şer'iyenin (şeriat hükümlerinin) kesin olarak yürütülmesi; Kabinenin toptan çekilmesi; Volkan gazetesinin ayaklanma öncesi ilan ettiği dört-beş herif-i naşerif'in sınır dişı edilmesi (Mebûsan Meclisi Başkanı Ahmet Rıza, İkinci Başkan Talat Paşa, Hüseyin Cahit, Rahmi ve Doktor Bahaeddin Şakir Beyler); Harbiye Nazırı Ali Rıza Paşa, Sadrazam Hüseyin Hilmi ve Birinci Ordu Komutanı Mahmut Muhtar Paşa'nın azledilmesi; Mektepli

${ }^{52}$ Ayasofya Meydanı'nda; Tophane'deki İstihkam Taburu, Kılıç Ali Paşa'daki askerler, Beyoğlu'ndaki Topçu Numune Alayı, Yıldız'daki 5, 6 ve 7 nci Alaylar, Bahriye Nezaretindeki erler, beyaz, kırmızı ve yesil bayraklarla cevrili alanda yerlerini almıslardır. Bkz., Bayur, Türk Inkllabı Tarihi, C. I, s. 184; Karal, Osmanlı Tarihi, Ikinci Meşrutiyet ve Birinci Dünya Savaşı (1908-1918), C. IX, s. 85; Ertürk, s.36-37.

${ }^{53}$ Güresin, 31 Mart İsyanı, s. 44; Kırçak, Meşrutiyetten Günümüze Gericilik, s. 54-55.

${ }_{55}^{54}$ Güresin, s. 45.

${ }^{55}$ Padişah Abdülhamit, ayaklanmayı ancak saat sekiz civarında öğrenebilmiştir. Bu gecikmenin nedeni ise o dönemde İstanbul'da bir telefon hattının kurulmamış olmasıdır. Çünkü Abdülhamit telefonu kendisi için tehlikeli bir araç olarak görmektedir. Ayaklanma, Sadrazam Hüseyin Hilmi Paşa tarafından saraya yazılı olarak bildirilmiş ve daha sonraki saatlerde Meclis-i Mebûsan ile saray arasında telgraf bağlantısı kurularak, Abdülhamit tel aracılığıyla olayların gelişimini izlemeye başlamıştır. Kısa bir süre sonra Abdülhamit, isyancıların amaçlarını ögrrenebilmek için Şeyhülislam Ziyaettin Efendiyi görevlendirmiştir. Bkz. Güresin, 31 Mart Isyant, s. 45; Karal, s. 86.

${ }^{56}$ Güresin, s. 46 
subayların ordudan uzaklaştırılarak yerlerinin değiştirilmesi ve alaylı subaylardan açı̆̆a çıkartlarak mă̆dur edilenlerin yeniden orduya alınmalart; Alayl subaylara bu isyan hareketinden dolay sorumlu tutulmayacaklarını belgeleyen mühürlü bir senedin verilmesi; Şeriat yolunda yaplan her ayaklanmanın toplar atılmak suretiyle kutlanmast."

İsyancıların isteklerini öğrenen Şeyhülislam Ziyaettin Efendi, yapmış olduğu kısa konuşmasında ne gariptir ki, isteklerin haklı ve yerinde olduğundan bahsederek, durumu kabinedeki milletvekillerine ileteceğini ve sonucu bildireceğini söyleyerek olay yerinden ayrılmıştır ${ }^{57}$. Şeyhülislamın bu şekilde konuşması isyancıları büsbütün hareketlendirmiş ve isyancı liderler başlarında Kıbrıslı Derviş Vahdeti ve sarıklı hocalarla, bir meşveret kurup hükümetin değişmesini ve yeni kurulacak olan kabineye kimlerin gireceği işini de görüşmeye başlamışlardi ${ }^{58}$.

Kısa bir süre içinde İstanbul'un tüm semtleri isyancı erler tarafından kontrol altına alınmış ve medrese softalarından, İttihâd-1 Muhammedi Cemiyeti üyelerinden, asker ve çapulculardan oluşan gruplar, Bab-1 Âli'deki "Şûra-yı Ümmet" ve İttihatçıların sözcüsü durumunda olan "Tanin" gazetesinin bürolarını yerle bir ediyorlardı. Ayasofya alanındaki kalabalığın "şeriat isteriz" çı̆̆lıkları, daha sonra "kelle istemeye" dönüşmüştü Nitekim, kalabalığın kana susamış olduğu görülmekte olup, İstanbul'un üzerine bir dehşet ve anarşi havası çökmüştü. Osmanlı Kabinesi aynı gün saat 08.00'de toplanmış ve Şeyhülislam Ziyaettin Efendi de isyancıların isteklerini bildirmiştir. Görüşmelerin sonunda varılan karar ise son derece ilginçtir"60: "Kuvvet kullanılmasına gidilmeyecek, isyanciların isteklerinin kabul edildiği kararı Şeyhülislam aracılığıyla onlara ulaştırılacak ve ulemadan birkạ̧ kişi nasihat etmek üzere Ayasofya meydanı'na gönderilecekti."

Buradan da anlaşılacağı üzere padişah Abdülhamit, isyancılara karşı kuvvet kullanılmamasını ve kendilerine nasihat edilerek ayaklanmanın önlenmesini tavsiye etmişti. Fakat tarihte, özellikle Osmanlı tarihinde nasihat ile yatıştırılmış bir tek ayaklanma bulunmamasına rağmen sorumlular "Allah'ın dediği olur" sözlerine boyun eğerek, isyancıların elinde olan olayların akışına kendilerini kaptırmışlardır. Hükümet, almış olduğu bu kararları uygulama alanına koymaya çalışırken, isyancıların daha önce kuşatma altına almış oldukları Meclis binasını işgal etmeye başladıkları görülmektedir. Bu arada Milletvekili Sait Bey'in Meclisteki üyeler adına, "Muazzez askerlerimizin isteklerini incelemek ve bir sonuca bağlamak" adını

${ }^{57}$ Güresin, s. 46.

${ }^{58} \mathrm{Karal}$, C. IX, s. 86.

${ }^{59}$ Alaylı subayları ordudan çıkaracağı ve medrese softalarını sınavdan geçireceği ileri sürülen Harbiye Nazırı Ali Rıza Paşa, Meclis Başkanı Ahmet Rıza Paşa ve Hassa Komutanı Mahmut Muhtar Paşa'nın kelleleri isteniyordu. Bkz. Kırçak, Meşrutiyetten Günümüze Gericilik, s. 55; Tunaya, Islamcilık Akımı, s. 129.

${ }^{60} \mathrm{Karal}, \mathrm{C}$. IX, s. 87. 
taşıyan bir bildiri ile milletvekillerini toplantıya çağırması son derece önemlidir. Bu çağrıya 60 kadar milletvekili cevap vermiş ${ }^{61}$ fakat, milletvekillerinden bir kısmı Meclise ulaşmayı başaramamıştır. Özellikle, Adliye Nazırı Nâzım Paşa, Ahmet Rıza Bey'e benzediği için; Lâzkiye Milletvekili Aslan Bey de Hüseyin Cahit Bey sanılarak öldürülmüș ve Bahriye Nazırı Rıza Paşa da ağır yaralı olarak kurtulmuştu. Bütün bu olaylar Meclis üyelerinin gözünü büsbütün korkutmuş ve toplantıya 40 kadar milletvekili katılamamıştı́r ${ }^{62}$.

İşte Şeyhülislam, din adamları ve milletvekillerinin katılımıyla gerçekleşen bu toplantıda, asiler kabinenin çekilmesini, II. Tümen Komutanı Cevat Paşa ile Hassa Ordusu Komutanı Muhtar Paşa'nın yerlerinden atılmasını istiyorlardı. Bu arada ilmiye sınıfından Hoca Ahmet Rasim de Meclis kürsüsünden sözde asiler adına, gerçekte ise kendi sınıfı adına, din ile ilgili görüşleri ve istekleri içeren bir konuşma yapmışıır ${ }^{63}$ :

"Osmanlı Hükümeti bir İslam hükümeti olduğu için Müslümanlığın hükümleri yürütülmelidir, kanunlar din kitaplarından çıkarlmalıdır, askere namaz için vakit bırakılmalıdır, okul programlarına din dersleri konulmall ve İslam adetlerine aykır olan tiyatrolar kaldırılmalıdır, Müslüman kızlarla Hıristiyan kızlar arasında arkadaşlık olmaz, bu küfürdür, mebuslar ve kabine üyeleri dindar adamlardan oluşmalıdır."

Hoca Rasim'den sonra kürsüye İttihatçıların düşmanı, muhalefet lideri olan ve ayaklanmanın hazırlanmasında başrolü oynayan İsmail Kemal Bey gelerek, ayaklanmanın kabinenin taraf tutucu davranışından ve dar görüşlü davranmasından doğmuş olduğunu ve bir an önce düşürülmesi gerektiği konusunda görüşlerini dile getirmiştir ${ }^{64}$. Hoca Ahmet Rasim ve diğer isyancıların Meclisteki bu ateşli konuşmaları etkisini çok çabuk göstermiş ve Hüseyin Hilmi Paşa Kabinesi'ne güvensizlik oyu verilmiştir ${ }^{65}$. Millet Meclisi'nin bu kararından önce kabine zaten çekilmiş bulunuyordu. Özellikle Şurayı Ümmet ve Tanin basımevlerinin yağma edilerek milletvekillerinin öldürülmesi, kabine üyelerinin morallerini büsbütün bozmuş ve kabine Padişahın isteği üzerine istifa etmiştir ${ }^{66}$.

Kabinenin çekilmesinden sonra II. Abdülhamit ve isyancılar karşı karşıya gelmiş bulunuyorlardı. II. Abdülhamit'in isyancılara karşı kuvvet kullanması söz konusu olamazdı. Zaten ortada böyle bir kuvvet görünmüyordu. Görünse bile buna komuta edecek yürek, ilgililerde

${ }^{61}$ Bu milletvekilleri arasında İ́smail Kemal, Müfit ve Üsküp Milletvekili Sait Beyler de vardır. Bkz., a.g.e., s. 87

${ }^{62}$ Celal Bayar, Ben de Yazdım, C. I, İstanbul, Baha Matbaası, 1966, s. 276-280.

${ }^{63}$ A.g.e., s. 277-288; Karal, C. IX, s. 88

${ }^{64}$ Karal, C. IX, s. 88-89.

${ }^{65}$ Güresin, 31 Mart isyanl, s. 49.

${ }^{66}$ Enver Ziya Karal, Osmanlı Tarihi, İkinci Meşrutiyet ve Birinci Dünya Savaşı (19081918), C. IX, s. 88-89; Cevat Rıfat Atilhan, Bütün Çıplaklı̆̆ı Ille 31 Mart Faciası, 5. B., İstanbul, Bahar Yayınevi, 1972, s. 197-198. 
kalmamıştı. Padişah bu nedenlerden ötürü asilere Başkatip Ali Cevat tarafından kaleme alınan bir tezkere ile seslenmeyi uygun bulmuştu ${ }^{67}$ :

"Kabinenin çekilmesi Hazret-i zillüllah (Tanrının gölgesi olan II.Abdülhamit) tarafından kabul edilmiştir. Yeni kabine kurulmak üzeredir. Bugünkü ayaklanmada bulunan askerlerle diğer kimseler hakkında padişahımız genel af kabul etmiştir. Devletimiz Islam devletidir. Kıyamete kadar da öyle kalacakttr. Seriat bundan böyle de daha büyük bir dikkatle yürütülecektir. Başkomutan olan büyük Halifemiz Padişahımız askerlere kışlalarına, ahaliye de iş ve güçlerine dönmelerini bildirir ve selamlar."

Padişah tezkeresi isyancıların gönüllerini alacak şekilde kaleme alınmış ve yazıda "Meşrutiyet", "Kanun-i Esaŝ̂" sözcüklerine yer verilmemiştir. Buna karşılık istibdat devirlerinde padişahın kullandığı "Tanrının Gölgesi" deyimi tekrar ortaya çıkmıştır. Bu tezkere önce Meclis'te, sonra da Ayasofya'da bulunan isyancılara "şeriat isteriz" sesleri arasında okunmuş, bu arada tezkerenin şeriat ile ilgili sözüne de bir hoca, "...şimdiye kadar şeriat var mı idi ki, devam olunsun" diyerek tepkisini dile getirmiștir ${ }^{68}$. Sözü geçen tezkerenin okunmasından sonra isyancılar adına İsmail Kemal ve saray arasında yeni kabinenin kuruluşu için görüşmeler başlamıştır. Uzun görüşmeler neticesinde, isyancıların görüşleri doğrultusunda Tevfik Paşa'nın Sadrazamlığı ve Mareşal Ethem Paşa'nın da Harbiye Nazırlı̆̆ı üzerinde anlaşmaya varılmıştır. İsmail Kemal ise, Ahmet Rıza'dan boşalan Meclis Başkanlığı'na getirilmiştir. Böylece 14 Nisan 1909'da Tevfik Paşa Kabinesi kurulmuş ve göreve başlamıştır ${ }^{69}$.

İsyancıların zorbalığı yeni kabinenin kurulmasından sonra da devam etmiş, yapılan bu değişiklik ve "Aff-l Şahâne" adı verilen genel af isyancıları yola getireceğine aksine büsbütün azdırmıştır ${ }^{70}$. Ayaklanmanın birinci ve ikinci günü isyancılar, cinayetlerine bir yenisini eklemek üzere genç subayların peşine düşmüşler ve ele geçenlerden bazıları o anda kurşuna dizilmiş ve kimileri de ağır işkencelerle ve ancak ilkel yaratıkların duyacağı zevklerle kurban edilmişlerdir. Şerif Sadık Paşa ve Katibi Esat Bey, Süvari Teğmeni Selâhattin Mümtaz ve Üsteğmen Yusuf Nurettin öldürülenler arasındadır ${ }^{71}$. Bütün bu cinayetlerle de yetinmeyen isyanciların, İstanbul içerisinde küçük gruplar halinde dolaşarak silah atmaya, Türk kadınlarının Beyoğlu'na çıkmasına engel olmaya, Frenk gömleği giyen kimseleri

${ }^{67}$ Faik Raşit Unat, 31 Mart İsyant-Ali Cevat..., s. 92.
${ }^{68}$ A.g.e., s. 50; Karal, C. IX, s. 90.

${ }^{6}$ Bayur, Türk Inkılabı Tarihi, C. I, Ks. II, s. 188; Karal, Osmanlı Tarihi, İkinci Meşrutiyet ve Birinci Dünya Savaşı (1908-1918), C. IX, s. 90.

${ }_{70}$ Milletvekillerinin canice katledilmesinden sonra, Süvari Müfrezesinin başında Divan Yoluna ilerleyen Yüzbaşı Romülüs İpatari, asi bir avcı neferi tarafından öldürülmüştür. Bkz. Güresin, 31 Mart isyant, s. 51.

${ }^{71}$ Yıldız Kışlası Subaylarından 6'sı mutfağa götürülüp ocak önünde tanrılara kurban edilir gibi boğazlanmışlardır. Köprü üzerinde İlyas isimli mektepli bir subay vurulmuş ve cesedi 24 saat ortada kalmış ve arabacılar ya korkudan, ya da taassuptan zavallı subayın cesedini taşımayı bile reddetmişlerdi. Bkz. Güresin, s. 51; Karal, C. IX, s. 91. 
tartaklamaya başladıkları görülecektir. Bunun yanı sıra beğenmedikleri subayların değiştirilmesi için listeler düzenleyip İsmail Kemal Bey aracılığıyla Harbiye Nazırı'na başvuruyorlardı. Ayrıca Cemiyet-i Muhammedi'nin kışkırtması ile softalar, eski casuslar ve yerlerini kaybetmiş istibdatçı memurlar da İstanbul ve taşrada Meşrutiyet taraftarlarının tamamen ortadan kaldırılması için yoğun çalışmalara girişmişti. Bu arada İttihat ve Terakki Cemiyeti ileri gelenlerinin oturdukları evler tespit edilmiş fakat bunların bir çoğu saklanarak canlarını kurtarabilmiştir ${ }^{72}$.

İsyancıların bu katliamlarından bir tanesi, 31 Mart Olayı'nın vahşetini ve Padişahın ilgisizliğini gözler önüne sermektedir. Bu korkunç olay ise, Asâr-1 Şevket Zırhlısı Kaptanı Deniz Binbaşılarından Ali Kubuli Bey'in, kendi gemisinin erleri tarafından sokaklarda sürüklenip, isyancıların çeşitli hakaretlerine uğrayıp, bu arada iki defa bayıldığı halde Yıldız Sarayı'na kadar götürülüp Abdülhamit'in gözleri önünde şehit edilmesidir. Zira Ali Kubuli Bey'in öldürülmesinde Abdülhamit'in tutumu son derece önemlidir ${ }^{73}$.

İsyanın donanma içinde de yayılması üzerine Binbaşı Ali Kubuli Bey, başlangıçta kendi askerlerinin asilerle birleşmesini önlemişti. Fakat bir konuşmasında, "Padişah, ancak millet olursa vardır. Milleti mahvetmek isteyenleri bu toplarla kahretmek boynumuzun borcu olmalıdır" sözleri kendisini linç edilmeye kadar götürmüştür. Özellikle İttihâd-1 Muhammedi mensupları ve hocaların propagandaları, askerler üzerinde etkili olmuş ve Binbaşının bu sözü şekil değiştirerek "donanma tarafından sarayın topa tutulacağı" söylentilerine dönüşmüştür. İşte buradan hareketle deniz erleri asilere katılmış ve Ali Kubuli Bey, İstanbul'u ve Yıldız Sarayını topa tutmayı istemekle suçlandırılıp yakalanmış ve kafesli bir erzak arabasının içinde, başında bir imamla birlikte sarayın önüne götürülmüştür. Padişah II. Abdülhamit, sarayın penceresinden asilere ne istediklerini sorduğunda denizci erler $^{74}$, “...İstanbul'u topa tutacă̆ından ve gayet fena bir adam olduğundan dolayı Binbaşı Kubuli Bey'i getirmis olduklarını ve kendilerinin terfi-i rütbeden ve maaştan mahrum birakıldıklarını" dile getirmişlerdir. Padişah ise, "Bu adamı bana teslim edin, ben tahkik ederim" diyerek orada bulunan Başyaver Şakir ve II. Tümen Komutan Yardımcısı Veli Paşa'ya, Ali Kubuli Bey'i muhafaza altında karakola götürmeleri buyruğunu vermiştir. Fakat Abdülhamit pencereden ayrılınca erler, binbaşıyı orada canice öldürmüşler ve Padişah bunu duyduğunda "artık bunlar asker değil, yeniçeri-asi olmuşlar" diyerek endişesini dile getirmiştir ${ }^{75}$. Fakat bu arada Başkatip Ali Cevat Bey'in bu olay dolayısıyla bağırmasına müdahale eden

${ }^{72}$ Hüseyin Cahit ve Cavit Bey, önce Beyoğlu'nda bir dostlarının evinde gizlenmiş ve Hüseyin Cahit sonradan Rus Elçiliğine sığınmıştır. Rahmi, Talat ve Ahmet Rıza Beyler ise İstanbul'un çeşitli semtlerinde saklanarak hayatlarını kurtarmışlardır. Hassa Ordusu Komutanı Muhtar Pașa ise, Kadıköy'de komșusu olan İngiliz uyruklu bir zatın evinde saklanmış ve oradan da bir fırsatını bularak Alman vapuruyla Pire'ye, Pire'den de Selanik'e geçmiştir. Bkz., Karal, C. IX, s. 91.

${ }^{73}$ Faik Resit Unat, II. Mesrutivetin Illanı..., s. 60; Akșin, Ana çizgileriyle ..., s. 51.

${ }^{74}$ Unat, s. 61; Bayur, Türk Inkılabı Tarihi, C.I, Ks. II, s. 191-192.

${ }^{75}$ Akşin, Jön Türkler ve Ittihat Terakki, 2. B., Ankara, İmge Kitabevi, 1998, s. 185. 
Padişahın,"Başkatip ne bağırıyorsun? Bu asi herifleri bizim aleyhimize mi döndüreceksin, sarayı kurşuna ml tutturacaksın" diye azarladığı görülmektedir.

Görülüyor ki, vehimli Padişah II. Abdülhamit, Kubuli Bey'in sarayı topa tutacağına inanmış ve her olayı ince ince hesapladığı halde, Binbaşının iki yaverle karakola götürülemeyeceğini tahmin etmek istememiştir. Özellikle 14 Nisan'dan itibaren bir takım başıboş erler, Yıldız Sarayı önüne gelip "Padişahım çok yaşa" diye bağırmakta ve padişah ise pencereye gelip onları selamlamaktadır. Buradan da Abdülhamit'in askerin kendisinden yana olduğunu anlayınca işi demagojiye dökerek "asker öyle istiyor" diye dilediği adamları önemli kilit noktalarına yerleştirerek isyancıların bütün isteklerini yerine getirmesi de son derece düşündürücüdür. Bu açıklamalardan anlaşıllıyor ki, 13 Nisan ayaklanmasıyla Abdülhamit de, kontrolü yeniden ele alabileceği yolunda doğmuş olan ümit, verdiği buyruğun hiçe sayılarak Ali Kubuli Bey'in adeta kendi gözü önünde öldürülmesi ve öldürülenlere bir şey yapılamaması üzerine sönmüş ve hiç olmazsa gölgelenmiştir ${ }^{76}$.

31 Mart Ayaklanmasında asker İstanbul'a hâkim olmuş ve Meclis'te destek bulan yobazlar, isteklerinin yerine getirilmesini beklemeye başlamışlardı. Ne var ki, isyanın duruma hâkim oluşu, devleti tam olarak ele geçirmeye kadar götürememiştir. Bunda ise şüphesiz irtica hareketine karşı aydınların, subayların ve İttihat ve Terakki Cemiyeti'nin gösterdikleri tepkinin rolü büyüktür. Cemiyet kısa zamanda bütün şubeleriyle harekete geçmiş, bir yandan Padişah'tan durumun düzeltilmesi istenirken, öte yandan 2 nci ve 3 ncü Ordu'nun müdahalesi için talepler yapılmaya başlanmıştı ${ }^{77}$. $\mathrm{Bu}$ arada İttihatçıların önde gelen kişilerinden birisi olan jandarma Yüzbaşısı İsmail Canbolat'ın ayaklanmayı ve İstanbul'daki olayları bir telgrafla, "Meşrutiyet Mahvoluyor" şeklinde Selanik'e bildirdiği görülmektedir ${ }^{78}$ :

31 Mart Olayı, daha çok İttihatçılar aleyhinde bir seyir takip etmiş ve bununla beraber, "yeni olan her şey, şeriata aykırıdır" diye tahrip edilme yoluna gidilmişti. Rivayetlere göre, kravatlar koparılmış, kahvelerdeki resimler indirilmiş, hürriyet şarkıları yasak edilmiş plaklar kırılmış, açıklık iddiasıyla kadınlar tehdit edilmiş, kadın dernekleri basılmıştır. Bu hareketlerin adı da "çok şükür şeriatı kurtardık!" olmuştur. Mektepli subaylar birer düşman gibi görülerek birçoğu yaralanmış ve öldürülmüştür. Kısaca özetlemek gerekirse, İstanbul hürriyetle şeriatın çarpıştırılmak

${ }^{76}$ Bayur, Türk Inkılabı Tarihi, C.I, Ks. II, s. 192.

${ }^{\pi}$ Güresin, s. 58.

${ }^{78}$ İsmail Canpolat (1880-1926) İstanbul'da doğmuş ve 1899 'da Harp Okulu'nu bitirmiş ve Selanik ve Manastır'da görev yapmıștır. 1906'da Selanik'te kurulan Osmanlı Hürriyet Cemiyeti'nin kurucuları arasında yer almıştır. Bu derneğin İttihat ve Terakki Cemiyeti ile birleşmesinden sonra siyasal etkinliklerini yoğun bir şekilde sürdürmüş, Meşrutiyetin ilanından sonra İttihat ve Terakki'nin İstanbul'da örgütlenmesi için çalıșmıștır... 1924'te muhalif olarak kurulan Terakkiperver Cumhuriyet Firkası'na giren Canpolat, 1926'da Mustafa Kemal Paşa'ya karşı düzenlenen İzmir Suikastı'ndan sorumlu görülerek İstiklâl Mahkemesi'nde yargılanmış ve 14 Temmuz 1926'da İmir'de idam edilmiştir. Ayrıntılı bilgi için bkz. Çağlar Kırçak, Meşrutiyetten Günümüze Gericilik, s. 56. 
istendiği kanlı bir meydan haline getirilmiştir. Bozuk düzen fikirlere İslamcı bir şekil giydirerek şahsi menfaatler tatmin edilmek istenmiştir ${ }^{79}$.

İstanbul'dan gelen haber Selanik'te bomba etkisi yapmış, özellikle genç subaylar öfke ve endişe içinde olayların doğruluğunu öğrenmek için beklemeye başlamışlardı. Çünkü ayaklanmanın niteliği hakkında çeşitli söylentiler ortaya atılmıştı ${ }^{80}$. Bu söylentiler ise halkta büyük bir heyecan uyandırmış, Makedonya'da İttihat ve Terakki Partisi'ne bağlılık, bir iman halinde kökleşmişti. Selanik Genel Merkezi ayaklanmaya zaman yitirmeden müdahale etmek için, ordunun yüksek komutanları ile görüşmüş ve III. Kolordu Komutanı Mahmut Şevket Paşa, Meşrutiyetin korunması için ant içmiş olan ordunun ayaklanmayı bastıracak güçte ve harekete hazır olduğunu bildirmişti $\mathrm{t}^{81}$. Bunun üzerine Genel Merkezin girişimi ile İttihatçı örgütlerden İstanbul'a protesto telgrafları yağmaya başlamıştır. Bunlar ise Padişaha, Sadrazam Tevfik Paşa ve Mebûslar Meclisi Başkanlığı'na gönderilmekte idi $^{82}$. Halkın isteği üzerine İttihat ve Terakki adına çekilen ilk telgrafta istibdat kabinesi olan Tevfik Paşa Hükümeti'nin değiştirilmesi istenmiş, fakat buna bir karşılık gelmeyince padişaha şu ikinci telgraf çekilmişti ${ }^{83}$ :

"Padişah, iftihar ediniz, yere batast bir gericilik hareketi ile Meşrutiyet yapıtı yıkılarak istibdat yönetimi tekrar kuruldu. Bütün bu milletin haklart korunacak yerde, bu gericilik hareketi büyük bir ustalıkla yürütüldü. İğrenç bir İstanbul halkının kötü isteklerine uyularak otuz milyonluk büyük bir milletin yok edici ellere geçirilmesi istendi. Fakat ne mümkün, o cehennemliklerin görecekleri, başar değil mezar olacaktır."

Telgrafta bundan sonra millet ve ordunun İstanbul üzerine yürümekte olduğu, alçakların derhal darağacına çekileceği belirtilerek "bizim için ölmek var dönmek yok" parolası açıkça vurgulanmakta idi. Abdülhamit, İstanbul'da gerici ayaklanmanın başarıya ulaştığını görünce, İttihat ve Terakki Partisi'nin memlekette köklü bir güce ve etkiye sahip bulunmadığını zannetmişti. Bu yüzden Makedonya'dan ilk gelen protesto telgraflarına önem vermeyerek "blöften ibaret" diye vasıflandırmış ve telgrafların arkası kesilmeyince ve Makedonya'da halkla ordunun ve İttihatçıların birlik olduğunu anlayınca sinirlenmiş ve hiddetini şu sözlerle dile getirmişti ${ }^{84}$ : "Rumeli'den kendilerinin getirmis olduklarl askerler, kendilerine karşı ayaklanmıslar, herifleri namazdan, niyazdan yoksun ettiler. Baskı yaptılar, isyan ettirdiler. Bizim ne kabahatimiz var, biz ne yapalım?"

${ }^{79}$ Tunaya, Islamcllık akımı, s.131.

${ }^{80}$ Bu söylentiler Mebuslar Meclisi'nin basıldığı, bir kısım milletvekillerinin öldürülerek yerlerine başkalarının atanmış olduğu, Galata Köprüsü'nün havaya uçurulduğu ve sansürün tekrar uygulama alanına konulduğu şeklindedir. Bkz. Faik Reşit Unat, II. Meşrutiyet...Ali Cevat, s. 64 .

${ }^{80}$ Karal, C. IX, s. 97.

${ }^{81}$ A.g.e., s. 97.

${ }^{82}$ İsmail Hami Danişmend, 31 Mart Vak'ast, s. 38; Karal, C. IX, s. 97.

${ }^{83}$ Danişmend, s. $37-38$.

${ }^{84}$ Faik Reşit Unat, Ali Cevat, s.64; Karal, C. IX, s. 98. 
İstanbul'da patlak veren irtica hareketini bastırmak için Selanik'ten İstanbul'a kuvvet gönderilmesi kararlaştırılmış ve Selanik'te bir yandan ordu birlikleri hazırlanırken, öbür yandan da gönüllü toplama işi tüm hızıyla devam etmekte idi. Üçüncü Ordu Birlikleri İstanbul'a yürümeye hazırlanırken, bu birliklere Edirne'de bulunan İkinci Ordu Birlikleri ve Selanik çevresinde sivil gönüllülerde katılıyordu. Özgürlük kahramanı olarak tanınan Resneli Niyazi Bey'de, Resne'de bir araya getirdiği gönüllülerle birlikte bu hareketin içinde yer almıştı. Tüm bu kuvvetlerin Yüksek Komutanlığını Mahmut Şevket Paşa, Komutanlığını Hüseyin Hüsnü Paşa, Kurmay Başkanlığını da Önyüzbaşı (Kolağası) Mustafa Kemal (Atatürk) üzerine almıştı. Selanik Redif Tümeni ise sözü edilen kuvvetin çekirdeğini oluşturuyordu ${ }^{85}$. Bu suretle meydana getirilen kuvvete Mustafa Kemal'in uygun gördüğü "Hareket Ordusu" adı verilmiştir ${ }^{86}$. Atatürk, bu ismin konulmasını şöyle aç่ılamaktadır ${ }^{87}$ :

"Irticai bastırmayı üzerine alacak askeri kuvvetimiz için bir isim düşünmüştüm. Öyle bir isim olmasını istedim ki, çarpışan tarafların duygularına dokunmasin... Herkes bu ismi benimseyebilsin... Fransizca "Mouvement" manasina gelen hareket kelimesi aklıma geldi. Zaten yürüyüş halindeydik. Kuvvetlerimizin adı 'Hareket Ordusu' oldu."

Hareket Ordusunun öncü birlikleri 14 Nisan akşamı trenle İstanbul'a hareket etmiş ve ordu kuvvetlerinin toplantı yeri olarak Yeşilköy gösterilmiști $^{88}$. Nitekim, 14-19 Nisan arasında Hareket Ordusu kuvvetleri İstanbul'u Batıdan yarım çember içine almış ve 19 Nisan'da bu kuvvetlerin komutanı Hüseyin Hüsnü Paşa, İstanbul halkına bir bildiri yayımlamıștır. Devrimci bir biçimde Mustafa Kemal tarafından kaleme alınan bu bildiride, Hareket Ordusunun amaçları şöyle açıklanmaktadır ${ }^{89}$ :

${ }^{85}$ Karal, C. IX, s. 98; Kırçak, s. 56-57; Ertürk, İki Devrin Perde Arkası, s. 41.

${ }^{86}$ Bütün bu tedbirlerin alınmasinda ön ayak olan, daha sonra Arıburnu ve Anafartalar'da, Ulusal Bağımsızlık Savaşı'nda siyasi tarihin akışını değiştirdiği için o zaman ki İngiliz Deniz İşleri Bakanı Churchill'in, "kaderin adamı" dediği Önyüzbaşı Mustafa Kemal Bey'dir. Mustafa Kemal, o sırada Selanik Redif Tümeni'nin Kurmay Bașkanı'dır. 14 Nisan sabahı Redif tümenine gelen telgrafları inceleyen Mustafa Kemal, İstanbul'da olağanüstü bir durumun olduğunu sezmiş ve arkadaşlanyla görüşerek tek çarenin İstanbul'a kuvvet sevk etmek olduğunu anlatmıstır. Bu düsüncesini Ordu Komutanı Mahmut Sevket Paşa'ya kabul ettirmiştir. Ordu Komutanı, hazırlanan bu kuvvetin başına Hüseyin Hüsnü Paşa'yı ve Kurmay Başkanlığına da Mustafa Kemal'i atamıs ve "Hareket Ordusu" adı ile anılan bu kuvvet, Istanbul'u bir hafta içinde asilerden temizleyecektir. Bu ordunun tertibi, kararı, sevki ve İstanbul'a kadar idaresi tamamen Mustafa Kemal'in eseridir ve her şey onun planlarına göre olmuştur. Bkz. Bayur Türk Inkılabı Tarihi, C.I, Ks. II, s. 197; Mustafa Ragıp Esatlı, Ittihat ve Terakki, İstanbul, Hürriyet Yayınları, 1975, s. 28; Akşin, s. 52-53; Kazım Özalp ve Teoman Özalp, Atatürk'ten Antlar, 4. B., Ankara, Türkiye İş Bankası Kültür Yayınlar1, 1998, s. 3-4

${ }^{87}$ Bayar, Ben de Yazdım, C. I, s. 80; Güresin, s. 59.

${ }^{88}$ Karal, C. IX, s. 98.

${ }^{89}$ Beyannamenin aslı için bkz., Bayur, Türk Inkılabı Tarihi, C.I, Ks. II, s. 200; Faik Reşit Unat, Ali Cevat, s.138; hareket Ordusu'nun İstanbul'a yürüyüşü için bkz., Ali Mithat İnan, Atatürk'ün Not Defterleri, Ankara, Gündoğan Yayınları, 1996, s. 61-62. 
"Millet Anayasanın ayaklar altına alınmak istendiğini gördü ve bu alçakça harekete sebep olanlarl cezalandırmak gereğini kavrayarak İstanbul üzerine yürümeye karar verdi... Hareket Ordusunun amaç ve ödevi, Anayasa'nın üstünde hiçbir kanun, hiçbir kuvvet olmadığını ve olamayacă̆ını ispat eylemek... ve millet hainlerine son ve kesin bir uyarıcı ders vermektir... Mazlum ahâli ve tarafsız erat kesin olarak korunacaktır. Ancak kışkırtıcılar, fesatçılar ve onlara katılmış olanlar hak ettikleri kanun cezasından hiçbir suretle kurtulamayacaklardır."

Bu beyanname Mustafa Kemal'in üslûp ve düşünce tarzını çok güzel bir şekilde yansıtmaktadır. Aynı gün yine Hüseyin Hüsnü Paşa imzasıyla, Mustafa Kemal'in yazmış olduğu bir telgraf, İstanbul'da Genelkurmay Başkanlığı'na çekilmiş ve sokaklarda halka dağıtılmıştır ${ }^{90}$. Bu telgrafta Mustafa Kemal'in; Meşrutiyetin ilanını yalnızca İttihat ve Terakki ve ona bağlı subaylara değil, bütün millete mal etmekte olduğu çok iyi anlaşılmaktadır. Adı geçen telgrafta Mustafa Kemal, Osmanlı Ordusu'nun "600 senelik lekesiz bir namus ve inkiyât ve itâat" taşımasını anarken, olayların verdiği coşkunlukla yeniçerilerin son yüz yıllardaki rezaletlerini, Patrona Halil ve Kabakçı Mustafa ayaklanmalarını çıkaranları ordudan saymamaktadır. Ayrıca, askerlerin bundan böyle siyasal işlere hiç karışmamaları yönünü, yani eskiden beri güttüğü başlıca amacı vurgulamaktadır ${ }^{91}$.

Meclis Başkanı İsmail Kemal Bey, Hareket Ordusu'nun İstanbul'a girmek kararında direndiğini öğrenince son kozunu oynamaya çalı̧̧mıştır. Sözde böyle bir hareket İstanbul'da korkunç yağmalara ve kanlı olaylara yer verecekti. Bu gibi olayların önlenmesi de ancak büyük devletlerin girişimi ile mümkün olabilirdi ${ }^{92}$. Hareket Ordusu'nun İstanbul'a girmesini engellemek için, bu düşüncelerini uygulama alanına koyan İsmail Kemal Bey, Almanya başta olmak üzere Rusya ve İngiliz elçilikleriyle ilişkiye girmiş fakat olumlu bir sonuç alamamıştır. Ayrıca Sadrazam Tevfik Paşa ile görüşmesine rağmen, Paşayı da ikna edemeyen İsmail Bey, kendisinin tutuklanmasıyla ilgili telgrafı öğrenir öğrenmez İngiltere Büyükelçiliği'ne sığınarak korunma talep etmiştir. İngiliz Elçisi Sir Gerard Lowthen ise daha sonra bu sadık adamını İngiliz bayrağı taşıyan bir vapurla Yunanistan'a kaçıracaktır ${ }^{93}$.

Bu arada Hareket Ordusu'nun İstanbul üzerine yürüyüşe geçmesi, İsmail Kemal Bey'in yakın çalışma arkadaşlarını da endişelendirmiş ve onların da bir çaresini bularak İstanbul'dan kaçmaya başladıkları görülmektedir. 31 Mart ayaklanmasının başlıca kışkırtıcılarının İstanbul'dan

${ }^{90}$ Orijinal Telgraf metninin başlıca kısımlan için bkz. Bayur, C. I, Ks. II, s. 202-203.

${ }^{91}$ Bayur, s. 203. s. 98.

${ }^{92}$ Karal, Osmanlı Tarihi, İkinci Meşrutiyet ve Birinci Dünya Savaşı (1908-1918), C. IX,

${ }^{93} \mathrm{Karal}$, C. IX, s. 101. 
kaçması, mevcûdu 40.000 olan isyancı askerleri gerçek liderlerinden yoksun bırakmıştı. Fakat görünmeyen eller özellikle Derviş Vahdeti önderliğindeki İttihâd-ı Muhammedi Cemiyeti ve yayın organı Volkan gazetesi, Padişah adına isyancılar arasında fitne ve fesat saçmaya devam ediyordu. Üstelik isyancilar da, cezalandırılacaklarından ve hatta öldürüleceklerinden korktukları için Hareket Ordusu'na karşı direnmeye kararlı gözüküyorlardı ${ }^{94}$.

Hareket Ordusu'nun İstanbul'a girmesiyle birlikte Selanik İttihat ve Terakki Merkezi, bir komuta değişikliğine başvurmuş ve Hareket Ordusu'nun Komutanlığı'na 3. Ordu Komutanı Korgeneral Mahmut Şevket Paşa'yı atamıştır. 21 Nisan 1909'da Selanik'ten yola çıkan Mahmut Şevket Paşa'nın 22 Nisan'da komutayı ele almasıyla birlikte, orduya bir tümen değil, bir "Kurtarıcı Milli Ordu" hüviyeti kazandırılıyordu". Komuta kademesindeki bu ani değişiklik üzerine Hüseyin Hüsnü Paşa ve Mustafa Kemal Bey, Şevket Paşa'nın emrine girmiştir ${ }^{96}$. Mustafa Kemal (Atatürk) bu değişikliği şöyle anlatmaktadır ${ }^{97}$ :

"Başlangıçta işlerin nasıl bir çap alıp gelişme gösterecekleri belli değil iken, Mahmut Şevket Paşa dâhil tanınmış kimselerin hiç birisi, üzerine esaslı bir sorumluluk almiyor ve herkes benim söylediklerimi kabul etmekle yetiniyordu. Doğru ve kendi halinde bir komutan olan Hüseyin Hüsnü Paşa'yl bu işin başına geçmesine ben inandırdım ve O'nun başa geçirilmesini Mahmut Şevket Paşa'ya ben kabul ettirdim. Durum karanlık ken bir Redif Tümeni Komutanı için İstanbul'u kurtarmak işinin fazla olduğunu kimse ortaya atmadt. Ancak Istanbul'a yaklaşılıp karşı tarafta ne padişahın, ne de ayaklanma elebaşılarının hiçbir hareketi görülmeyince, oradaki askerlerin başı boş bırakıldıkları ve hele girişilen irtica hareketini bütün yurda ve öbür ordulara yaymak için ciddi biçimde çalışılmadığ sezilince, işin yalnızca birkaç bin ayaklanmıs eri yakalamaktan ibaret olacă̆ı anlaşılmıştı. Bunun üzerine Mahmut Şevket Paşa, Selanik'ten gelip ordunun başına geçmiş ve bilinen çalımla Istanbul'a girmiştir. Ayrica Enver ve daha birkaç Ittihat ve Terakki subayı ve Ataşemiliteri, İstanbul surları önünde Hareket Ordusu'na katılmıs, gazetelerde hep onların adı geçmiştir."

Hareket Ordusu Kurmay Başkanlığı'nın Önyüzbaşı Mustafa Kemal'den alınıp Binbaşı Enver Bey'e verilmesi hiçbir şeyi değiştirmeyecektir. Zira o sırada hastalanan Mustafa Kemal'in adı, Trablusgarp Savaşı'na kadar hiç

${ }^{94}$ A.g.e., s. 101.

${ }^{95}$ Bayur, Türk Inkalabı Tarihi, C.I, Ks. II, s. 204; Güresin, s. 60.

${ }^{96} \mathrm{Bu}$ ani komuta değişikliği hakkında çeşitli görüşler ileri sürülmektedir. Özellikle bu ani değişiklikte Enver Bey'in payı bulunduğu ve kendisinin ayaklanma patlak verdiğinde Ateşe-militer olarak Berlin'de görev yaptığı ve olayı haber aldığında hemen Selanik'e geldiği bilinmektedir. Nitekim, Enver Bey'in Selanik'te kalmayarak Ayestefanos'a (Ordu Karargahına) gelmesi ve Kurmay Başkanlık görevinin Mustafa Kemal'den alınarak kendisine verilmesi bu olasılığı güçlendirmektedir. Bkz. Kırçak, Meşrutiyetten Günümüze Gericilik, s. 58.

${ }^{97}$ Bayur, Türk Inkılabı Tarihi, C. I, Ks. II, s. 203-204. 
duyulmayacaktır. Bu durum Mustafa Kemal'in, politika ile askerliği birbirinden ayırmak yolunda vermiş olduğu uğraşılarının ve hiçbir siyasal kuvvete alet olmaya tenezzül etmeyişinin bir sonucu olarak da değerlendirilebilili ${ }^{98}$.

31 Mart İsyanı'nın koşulları Anadolu'da hazırlanmış olduğu için, merkezi İstanbul olan bu isyanın tepkileri Anadolu'nun bazı yerlerinde de görülmüştür. Bursa, Erzincan ve Erzurum'da meydana gelen olaylar, hükümet otoritesinin zayıflığından ve dinci-çıkarcı iş birlikçilerin kışkırtmalarıyla meydana gelmiştir. Ayrıca Anadolu'da İttihat ve Terakki Partisi merkezlerinin yeni kurulmaya başlanması ve Makedonya'daki gibi kuvvetli olmaması, adı geçen olayların büyümesine neden olmuştur ${ }^{99}$.

Anadolu'da meydana gelen ayaklanmalarda özellikle Doğudaki gelişmeler son derece önemlidir. Çünkü Erzincan ve Erzurum askeri birliklerin en yoğun olduğu iller kapsamındadır. Oralarda meydana gelecek ayaklanma büyüdüğü takdirde, bütün Doğunun asilerin kontrolü altına geçme ihtimali çok yüksek olduğundan, bu amacı gerçekleştirmek ve idareyi ele geçirmek isteyen İttihâd-1 Muhammedi Cemiyeti'ne, Osmanlı Devleti'nin kaderi teslim edilmiş olacaktı ${ }^{100}$.

İstanbul'da asker arasında yapılmış olan kışkırtmalar, Erzincan'da da kendini göstermiş ve ayaklanma öncesi askeri okul öğrencileri ile okullu subayların öldürüleceği, şeriat isteneceği yolunda fisıltılar kulaktan kulağa dolaşmaya başlamıştı. Şeriattan başka, alaylı-okullu subay sorununu da sömüren dinciler ile çıkarcılar birleşerek, 13 Nisan 1909'da harekete geçmişlerdir. Erzincan Askeri Garnizonu'nda bulunan askerler, sancaklarına Kur'ân-1 Kerim bağlayıp silahlı olarak bir süvari başçavuşunun komutasında Koşu Meydanı'nda toplanarak, şeriatla ilgili isteklerini duyurmuşlardır ${ }^{101}$. Fakat, Erzincan'daki 4 ncü Ordu Komutanı Müşir İbrahim Paşa, yanında Erzincanlıların çok sevdikleri Şeyh Hacı Fevzi Efendi olduğu halde, isyancılarla görüşerek tavsiyelerde bulunmuş ve isyanı fazla büyümeden bastırmayı başarmıştır ${ }^{102}$.

Erzurum'daki ayaklanma ise, yine Tümen Komutanı Yusuf Paşa'nın kışkırtma ve destekleriyle meydana gelmiştir. Tıpkı Erzincan İsyanı gibi

${ }^{98}$ Bayur, C.I, Ks. II, s. 198

${ }^{99}$ Karal, C. IX, s. 92.

${ }^{100}$ Güresin, , s. 54.

${ }^{101}$ İsyancılara komuta eden Süvari Başçavuşu, Erzurum Tümen Komutanı Yusuf Paşa tarafından desteklenmiştir. Bkz. Güresin, s. 54.

${ }^{102}$ Erzincan İsyanının sona erdirilmesinde İbrahim Paşa'nın, daha önceden isyancıların arasına soktuğu Yzb. Kemalettin Sami Bey'in büyük yardımları olmuştur. Kemalettin Sami Bey'in görevi, kışkırtılmış askerin isyancılara katılmasını önlemekti. Ayrıca İbrahim Paşa'nın cesareti ve kararlılığı son derece önemlidir. İsyancı komutanın kısa bir tartışma sonrası tüfeğini İbrahim Paşa'ya çevirmesi ve Paşa'nın tüfeği eliyle iterek kamçısını Başçavuşun yüzüne vurması, isyanın en önemli noktasını teşkil eder. İsyancıların bile dehşetle izledikleri bu dayak sahnesi Erzincan Ayaklanması'nın kaderini değiștirmiștir. İbrahim Paşa'nın görevi askerin kışlasına dönmesini sağlamaktı ve bunda da başarılı oldu. Bkz. Celal Bayar, Ben de Yazdım, C. I, s. 159-160; Güresin, s. 55-56. 
başlayan olayların önlenmesi, çok daha kolay olmuştur. Başta 4 ncü Ordu Komutanı İbrahim Paşa olmak üzere Ömer Naci, Kolağası Halil Bey, Teğmen Yakup Cemil ve Filibeli Hilmi gibi ateşli İttihatçıların müdahalesiyle bu ayaklanma da etkisiz hale getirilmiştir ${ }^{103}$. Bu arada Erzincan ve Erzurum ayaklanmalarında baş rol oynayan isyancı Tümen Komutanı Yusuf Paşa da tutuklanarak İstanbul'a gönderilecek ve Örf-i İdare Mahkemesi'nde idama mahkûm edilecektir.

İstanbul dışında meydana gelen bu ayaklanmaların yanı sıra Bursa, Bergama, Karahisar, Diyarbakır, Van, Medine ve Şam'da da ufak çaplarda gerici hareketlere rastlanılmıştır Bursa'nın İstanbul'a yakın olması ve dinci örgütlerin çokluğu nedeniyle, İttihâd-1 Muhammedi Cemiyeti burada şubeler açmak ve çalışmalarını geliştirmek amacıyla elverişli bir ortam bulmuştu. İstanbul'daki ayaklanmanın duyulması üzerine, Bursa İttihâd-1 Muhammedi Cemiyeti mensuplarının 14 Nisan 1909'da büyük bir gerici gösteriyle bu ayaklanmayı destekledikleri görülmektedir ${ }^{104}$. Binlerce insan ellerinde yeşil bayraklarla şehir içindeki telgrafhanenin önünde toplanarak, İstanbul'daki İttihâd-1 Muhammedi Cemiyeti Merkezi'ne, Kıbrıslı Derviş Vahdeti'ye ve Millet Meclisi'ne telgraf çekerek isyancılarla birlikte olduklarını açıklamışlardır. Öte yandan hocaların ve şeyhlerin katıldığı bir topluluğun, Tophane Meydanı'nda tekbirler getirip dua ettikleri de görülmüştür. Bursa olayları uzun tartışmalardan sonra hükümet yetkililerin almış oldukları tedbirlerle kan akıtılmadan bastırılabilmiştir. Bunun yanı sıra 15 Nisan'da İstanbul'dan gelen silahlı bir isyancı grubunun da olay çıkarmasına meydan verilmemiştir $^{105}$.

Mahmut Şevket Paşa, 21 Nisan 1909'da İstanbul önlerine gelmiş olan Hareket Ordusu'nun komutanlığını almak üzere Selanik'ten ayrılacağı sırada, Saray'da toplanmış olan Vükelâ Meclisi üyelerinden Şurâ-yı Devlet Reisi Raif Paşa ve Maarif Nazırı Abdurrahman Şeref Bey ile telgraf vasıtasıyla bir görüşme gerçekleştirmişti ${ }^{106}$. Yapılan bu görüşmede Mahmut Şevket Paşa, "Meşrutiyet severlerin genel isteğ $i$ üzerine Hareket Ordusu İstanbul dolaylarını ele geçirdi, amaç ayaklanmış olan askeri yeniden disiplin altına almak, irtica olayına sebep olanlarl yargılatıp gerekirse

${ }^{103}$ İbrahim Paşa, Erzurum'a gelerek isyancıların üzerine bir süvari müfrezesiyle baskın yapmıştır. Bu müfrezenin, Erzincan'dan yola çıkan ordu birliklerinin öncüsü olduğunu zanneden asker silahını bırakmış ve teslim olmuştur. Bkz. Güresin, s. 56.

10414 Nisan'da Adana'da başlayan ayaklanma gerici nitelikli olmayıp, Ermenilerle Müslümanlar arasında çıkan bir iç hesaplaşma olarak değerlendirilebilir. Adana'da yağma ve yangınlara neden olan bu silahlı çatışma çok kanlı bir biçimde bastırılmıştır. Nitekim, Adana Ayaklanması Abdurrahman Şeref Bey'in deyimiyle "Hürriyet neşesinin kanlı sarhosluğu" olarak tarihe geçmiştir. Bkz., Tunaya, Islamcılık Akımı, s. 132; Karal, Osmanlı Tarihi, Ikinci Meşrutiyet ve Birinci Dünya Savașl (1908-1918), C. IX, s. 92; Tanin Gazetesi, 10, 11, 15 Mayıs ve 4 - 11 Haziran 1925 tarihli sayılar.

${ }^{105}$ Tunaya, Islamcılık Akımı, s. 132; Abdurrahman Şeref, "Sultan Abdülhamit Han-i Saniye Dair", s. 40.

${ }_{106}$ Abdurrahman Şeref, "Sultan Abdülhamit Han-i Saniye Dair", s. 44; Bayur, Türk Inkılabı Tarihi, C. I, Ks. II, s. 207. 
cezalandırmak ve Kanun-u Esasîye sadık kaldıkça makam-ı saltanata ilişilmemek" sözlerini vermiştir ${ }^{107}$.

Hareket Ordusu Komutanı Mahmut Şevket Paşa, 22 Nisan'da Yeşilköy'e gelmiş ve ilk işi 1 nci Ordu Komutanı Nazım Paşa ile görüşmek olmuştur. Aynı gün Âyan ve Mebûsan Meclisi üyelerinin bir kısmının Yeşilköy'e gelerek tek Meclis halinde Âyan Reisi Sait Paşa'nın Başkanlığında toplandığı ve İstanbul Hükümeti ile temasa geçtiği de görülmektedir.

Yeşilköy'de toplanan ve Ahmet Rıza Bey'in yerine Sait Paşa'yı Başkanlığa getiren Millet Meclisi, ilk iş olarak Abdülhamit'in hal'i (tahttan uzaklaştırılması) meselesini ele almıştır. Milletvekilleri 31 Mart İsyanı'nın kızgınlığı ve yurdun her tarafından gelen bağlılık telgraflarının heyecanıyla padişahı tahttan indirmek istiyorlardı. Fakat Mahmut Şevket Paşa, böyle bir harekete sıcak bakmıyor ve bu davranıș zamansız ve gereksiz buluyordu ${ }^{108}$. Çünkü, Hareket Ordusu Rumeli'den Meşrutiyetle beraber, Padişahı ortadan kaldırmak isteyen asileri cezalandırmak için yola çıkmıştı. Tersine bir davranış, Hareket Ordusu'nun bir kısmını veya tamamını isyancılar tarafına geçirebilir ve Osmanlı İmparatorluğu sonsuza dek karanlığa gömülebilirdi. Zaten isyancıların önemli bir bölümü Yeşilköy ve çevresinde dolaşarak Rumeli'den gelen askerleri kışkırtmaya çalışıyorlardı.

Mahmut Şevket Paşa'nın bu görüşlerini dikkate alarak kararlarını yeniden gözden geçiren Millet Meclisi'nin, 22 Nisan'da İstanbul Hükümeti'ne göndermiş olduğu tezkerede, "padişahın Anayasaya sadık

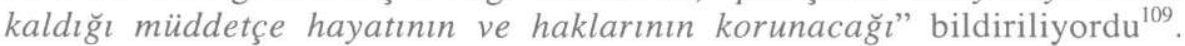
Ayrıca Mahmut Şevket Paşa'nın, 23 Nisan 1909'da padişaha çekmiş olduğu telgrafta, "İkinci Ordunun gelişi dolayısıyla bir takım kötü niyetlilerin kendisinin hal' edileceği haberlerini çıkarttıklarını, ancak bunların aslı olmadı ̆̆ıı" bildirmesi de son derece önemlidir ${ }^{110}$.

Görüleceği üzere bütün bu çalışmalar ve verilen teminatların amacı Padișah ve hükümete gözdağı vererek korkutmak, her türlü karşı koymayı engellemek, daha fazla kardeşkanının dökülmesine mani olmak ve kışlalardaki askerleri yola getirerek yapılacak müdahaleyi hukuk kuralları içerisine oturtmaktı ${ }^{111}$.

${ }^{107}$ Bayur, Türk Inkilabı Tarihi, C. I, Ks. II, s. 207.

108 Âyandan Sahip Molla, Sait Paşa ile görüşüp ona, “...Fetva-yı şerif çıkaralım, padişahı hal' edelim; beyhude Müslüman kanı akıtmayalım" demiş, $\mathrm{O}$ ise bunu kabul etmeyerek Mahmut Şevket Paşa ile görüşmek istemiş ve Paşa'ya "Padişah meselesi ne olacaktır?" diye sormuştur. Mahmut Şevket Paşa ise, "Bizim vazifemiz âsileri tenkildir. Padişah hakkında karar vermek Millet Meclisi'ne aittir" karşılığını vermiştir. Bkz., Cumhuriyet Gazetesi, Halil Menteșe'nin Hatıraları, 22 Ekim 1946, s. 2.

${ }^{109}$ Adı geçen tezkere için bkz. Bayur, Türk Inkılabı Tarihi, C. I, Ks. II, s. 29. II, s. 205

${ }^{10}$ Faik Reşit Unat, A.Cevat II. Meşrutiyet, s. 68; Bayur, Türk Inkılabı Tarihi, C. I, Ks. Güresin, 31 Mart Isyant, s. 60; Bayur, Türk Inktlabı Tarihi, C. I, Ks. II, s. 205. 
Hareket Ordusu'nun 23-24 Nisan gece yarısında İstanbul üzerine yürümeye başladığı görülmektedir. Sabaha karşı şehre giren öncü kuvvetler bazı önemli stratejik yerleri tutarak fiili işgali başlatmışlardır. Bu harekette öncü komutanları olarak Binbaşı Fethi (Okyar) Bey, Binbaşı Enver (Paşa) Bey, Binbaşı Ali Hikmet (Ayırdan) Bey ve Binbaşı Muhtar (Şehit) Bey görev almışlardı. Ayrıca Hafız Hakkı Bey, İkinci Ordu'dan İsmet (İnönü) Bey ve Kâzım (Karabekir) Bey gibi genç subaylar da bazı birliklere komuta ediyordu ${ }^{12}$. İsyancıların en yoğun direnme noktaları Taşkışla, Davutpaşa ve Taksim Kışlaları'nda olmuş ve kanlı çarpışmalar gün boyu sürmüştür ${ }^{113}$. Hareket Ordusu İstanbul'u asilerden temizledikten sonra birliklerini Yıldız Sarayı'na yönlendirmiştir. Yıldız Harekâtını ise Şevket Turgut Paşa yürütmekte, Fethi ve İsmet Bey, kendisine yardımcı olmaktadır. Şevket Turgut Paşa, Yıldız'da çok fazla muhafız askeri bulunduğundan şüphelenerek sarayı kuşatma altına almış ve beklemeye koyulmuştu. Halbûki, Hareket Ordusu'nun İstanbul'a girdiği gün Yıldız Sarayındakiler büyük bir korkuya kapılmış ve görevlilerden pek çoğu bir yolunu bularak kaçmışlardı. 25 Nisan'da başlayan kuşatma iki gün sürmüş ve 27 Nisan'da Hareket Ordusu saraya girerek kontrolü ele geçirmiştir ${ }^{114}$.

\section{Olayın Sonuçları}

Padişah Abdülhamit'in, Hareket Ordusu'na karşı direnmemesinin nedeni, kendisine verilen teminatlarla ilgili olduğu bilinmektedir. Ayrıca, Ordu Komutanı Mahmut Sevket Paşa'nın izlemis olduğu bu politika ile Padişah etkisiz hale getirilmiştir. Gerçekten Abdülhamit, Yıldız'daki İkinci Fırka'ya direnme emrini verseydi ve Saray muhafızları da onlara karışmış olsaydı, savaş uzun sürecek ve Yıldız'dan kuvvet alan isyancı askerlerde cesaretlerini artıracaklardı. Böylece Hareket Ordusu'nun ezilmesi veya uzun süre bir direnişle karşıllaşması sonucunda, Osmanlı İmparatorluğu içinde muhakkak bir iç savaşın çıkma ihtimali çok yüksek olacak, Rumeli elimizden çıkacak ve kapıda bekleyen Batılı devletlerin her an bir saldırısıyla karşılaşabilecektik. Nitekim hemen şunu da belirtmekte yarar var ki, eğer Mahmut Şevket Paşa ve emrindekiler, günün heyecanına kapılıp Abdülhamit'i derhal devirmeye kararlı olduklarını bildirselerdi, evhaml padişah belki de bir direnmeye karar verebilirdi ${ }^{115}$.

${ }^{112}$ Hürriyet kahramanlarından Niyazi (Resneli) Bey'in çeteleri Hareket Ordusu'nun bir kolunu teşkil ediyordu. Bazı eserlerde işgalde görev alan Hareket Ordusu, 25 Tabur ve 4 Alay şeklinde, bazılarında da 22 Tabur, 10 Süvari Bölüğü ve 9 Batarya olarak gösterilmektedir. Bkz., Güresin, s. 64; Kırçak, Meşrutiyetten Günümüze Gericilik, s. 58-59.

${ }_{113}$ Ordunun genç ve aydın bir subayı olan Kurmay Binbaşı Muhtar Bey, emrindeki müfrezesiyle Taksim Karakolu önünden Harbiye'ye doğru ilerlerken, karșllarına kışladan kaçan birkaç avcı askeri çıkmış ve çıkan çatışmada Muhtar Bey şehit düşmüştür. Bkz. Güresin, s. 66; Kırçak, Meşrutiyetten Günümüze Gericilik, s. 59.

${ }^{114}$ Sarayın kuşatma altında tutulduğu günlerde yapılan propagandalar, özellikle Sarayın direnmeye kalkışması halinde topa tutulacağı söylentisi yararlı olmuştu. Bu arada Sarayın elektrikleri kesilmiş ve 30 kadar muhafız avcı eri daha fazla dayanamayarak teslim olmuştur. Bkz. Karal, C. IX, s. 103.

${ }^{115}$ Güresin, s. 60-61. 
$\mathrm{Bu}$ arada, ayaklanmanın çıkarılmasında etkili olan siyasi partiler (İttihâd-ı Muhammedi, Ahrâr) ve mensuplarının iki taraflı çalışmaları da devam etmektedir. Özellikle bu partilere bağlı milletvekillerinin amacı, hem Abdülhamit'ten hem de İttihat ve Terakki'den kurtulmaktı. İşte Doktor Rıza Nur'un bu gergin ortamdan yararlanmak isteyerek harekete geçmesi de son derece düşündürücüdür. Rıza Nur, hatıratında bu konuyu şu şekilde açıklamaktadır ${ }^{116}$ :

“Bolu Meb'usu Habib, Meclis'te gizli bir celse yaptırıp kürsüye çıktı. Bütün mebusların Yeşilköy'e davet edildiklerini, derhal gitmeleri gerektiğini söyledi. Kandırdı. Baktım ki iş fena, Meclisi pençeleri alttna altp hareketlerinin meşruiyetini tasdik ettirecekler. Ondan sonra istedikleri gibi karar verdirecekler. Düşündüm, şehre girerlerse harp olacak... Halbuki bu olay ile Ittihatçılardan kurtulunacaktt. Böyle firsat bir daha ele geçer mi? Bunları burada bir daha ezip işi bitirmeli diye düşündüm. Ya Abdülhamit?... Dedim ki aynı zamanda onu da halletmek mümkündür. Derhal Harbiye Nezareti'ne gittim. Nazım Paşa'yı buldum. Bu zatla seviş̧irdik. İttihatçıları sevmezdi. Asker O'nu pek sever, ne dese dinlerlerdi. Hem de Harbiye Nazırı idi. Fakat bu sefer dermansiz halde buldum. Meseleyi ve fikrimi izah ettim: 'İş işten geçiyor. Sen şu askeri topla. 40 bin talimli askerin var. Şunları (Hareket Ordusu'nu) bir hamlede bitir. Ondan sonra da dön Abdülhamit'i hallet, işler düzelsin' dedim. Baktım, dudaklart morard, titremeye başlad. Gayet âciz ve perişan bir tavirla: ben bunu yapamam dedi."

Gerçekten Doktor Rıza Nur'un bütün ısrarlarına rağmen Nazım Paşa, böyle bir maceraya girişmekten kaçınmış ve Rıza Nur'da kurtuluşu Mısır'a kaçmakta bulmuştur. Nazım Paşa Hareket Ordusu'nun üzerine yürüseydi, onu ezebilir miydi? Rıza Nur'a göre belgeler göstermektedir ki Erzurum'daki ordu ve başka birlikler İstanbul üzerine yürümeye hazırdılar. Rıza Nur'un kendi amacına ulaşmak için Türk Ordusu'nu birbirine kırdırmak isteğini açıkça ileriye sürebilmesi, hırsların insanları nereye kadar götürdüğünü göstermesi bakımından son derece ilgi çekicidir ${ }^{117}$. Bu arada Hareket Ordusu'nun İstanbul'da duruma tamamen hâkim olmasıyla birlikte, Padişah II. Abdülhamit'in tahttan indirilmesi sorunu yeniden gündeme gelmişti. Ayaklanmanın tamamen bastırılmasıyla kendisini güvende hisseden Millet Meclisi'nin 25 Nisan'da Yeşilköy'den Ayasofya yakınındaki kendi binasına geri döndüğü ve 27 Nisan 1909'da son derece önemli olan bu olay için toplandığ 1 görülmektedir ${ }^{118}$.

Bu toplantıda, Padişah çıkarılan ayaklanmadan sorumlu tutulmakta ve Anayasayı koruyacağına dair yemin ettiği halde, ayaklanma sırasında bu doğrultuda herhangi bir olumlu girişimi görülmemiş̧i. Tersine isyancılara

${ }^{116}$ Doktor Riza Nur, Hatıralarım, s. 40; Güresin, s. 63.

${ }^{117}$ Güresin, s. 63-64.

${ }^{118}$ Bayur, Türk İnkllabı Tarihi, C. I, Ks. II, s. 209; Karal, C. IX, s. 103; Akșin, s. 54. 
para yardımında bulunduğuna dair elde deliller de vardı. Bu düşünce Millet Meclisi üyelerinin çoğunluğu tarafından da benimsenmişti. Nitekim, ayaklanma ile ilgili memleketin dört bir yanından gelen protesto telgraflarının okunmasıyla açılan Mecliste, ilk sözü Hareket Ordusu Komutanı Gazi Ahmet Muhtar Paşa alarak millet ve memleketin selameti için Abdülhamit'in tahttan indirilmesinin gerekli olduğunu dile getirmiş ${ }^{119} \mathrm{ve}$ Osmanlı Devleti'nin Anayasa hükümlerince Müslüman bir devlet olması nedeniyle bu konuda bir fetvaya gerek bulunduğunu sözlerine eklemiștir. Bu demeç, milletvekillerince de olumlu karşıllanmış ve Şeyhülislam Mehmet Ziyaettin Efendi ile Fetva Emini Hacı Nuri Efendi, hemen Meclise getirtilerek fetvanın hazırlıklarına girişilmesi oy birliğince kabul edilmiştir ${ }^{120}$.

Şeyhülislam ve Fetva Emini'nin Meclise gelmesi beklenirken, bazı sarıklı milletvekilleri (din hocaları) ile Elmalılı Hamdi Hoca'nın bir hâl' fetvası tasarısı hazırladıkları görülmektedir. Fakat hazırlanmış bu fetva tasarısını Fetva Emini Hacı Nuri Efendi beğenmemiş ve bu fetvayı vermemek için bir hayli direnmiştir ${ }^{121}$. Fetva Emini, Padişahın tahttan indirilmesinin uğurlu olmayacağını ve onun yerine kendisinin tahttan vazgeçmesi için çeşitli girişimlerde bulunulmasının yararlı olacağını dile getiriyordu. Ne var ki Abdülhamit'in bu düşüncelere son derece olumsuz baktığı, O'nun şu sözlerinden daha iyi anlaşılmaktadır ${ }^{122}$ :

\footnotetext{
"Ben saltanattan vazgeçmeyeceğim. Bu 31 Mart Olayı'nı bana isnât ediyorlar. Bunu hiçbir yönden kabul etmem ve sorumluluğunun ve lekesinin benim üstümde kalmasına razı olamam. Bir komisyon mu, yoksa bir yüksek divan mi kurulur. Her ne suretle olursa olsun tahkikat yapılsın. Bunu yapanlar meydana çıkarılsın, işte bu şartlarla ben saltanattan vazgeçerim".
}

Nitekim Meclis'te yaşanan bütün bu tartışmalara, iki türlü bir fetvanın hazırlanarak imzalanması şeklinde çözüm yolu bulunmuştur. Hem hâl', hem de istifa biçiminde hazırlanan fetva suretleri, Meclis genel oturumunda okunarak oylanmış ve Sultan Abdülhamit'in hilafet ve saltanattan

${ }^{119} 27$ Nisan 1909 Salı günü Meclis'te gerçekleşen bu oturum gizli olarak yapılmış ve Gazi Ahmet Muhtar Paşa, "Hepimiz içimizden hâl'e karar verdik, ancak iki yön, göz önünde tutulmalıdır. Birincisi bazen Osmanlı Tarihi'nde görüldü̆̆̈̈ gibi hareketimizi kana bulamayalım; Ikincisi bir fetva alalım, çünkü böylelikle taşra ahâlisini daha iyi tatmin etmiş oluruz. Bundan başka Veliaht Reşat Efendi'yi hemen getirtip ona biat edelim" şeklinde bir konuşma yapmıştır. Bkz., Abdurrahman Şeref Bey, "Sultan Abdülhamid'i Saniye Dair", s. 25; Bayur, Türk Inkılabı Tarihi,C. I, Ks. II, s. 210.

${ }_{120}^{120}$ Karal, C. IX, s. 104.

${ }^{121}$ Hacı Nuri Efendi'nin Fetva Eminliği'ne atandığı sırada, hiçbir biçimde hâl' fetvası vermeyeceğine dair Abdülhamit'e yemin etmiş olduğu söylenmektedir. Hacı Nuri Efendi bu işten sıyrılmak için Şeyhülislama, "Müftü-yül enâm zât-l âlileridir. Nasıl tensip buyurulursa o suretle icra ederler" diyerek tartışmaların büyümesine neden olmuştur. Bkz., Bayur, C. I, Ks. II, s. 211

${ }_{122}$ Faik Reşit Unat, II. Meşrutiyetin Ilanı ve 31 Mart Hadisesi-Ali Cevat Beyin Fezlekesi, s. 98; İsmet Bozdağ, Sultan Abdülhamit'in Hattra Defteri, 10. B., İstanbul, Pınar Yayınları, 1995, s. 102-103. 
indirilmesiyle ilgili olan fetva sureti oy birliği ile kabul edilmiştir ${ }^{123}$. Şeyhülislam Mehmet Ziyaettin Efendi imzasıyla yayınlanan bu fetva sureti ${ }^{124}$, Osmanlı tarihinde verilmiş olduğu bilinen birçok fetvalar gibi din ile devletin birleşmiş olmasının bir sonucu olarak, dinin siyasete alet edildiğini gösteren parlak bir örnektir. Fetvada, "Abdülhamit'in yasalara uymadı $\breve{g}_{l}$, devlet hazinesinden gereksiz harcamalar yaptı $\breve{g}_{l}$, yasal dayanaklar olmaksızın kişileri sürgüne gönderdiği ve öldürttü̈̆̈̈̈, bunları yapmamaya yemin ettiğ $i$ halde yeminini bozduğu, Müslümanlar arasında kargaşa yarattı̆̆ ve iç savaşa neden olduğu" söylenmekte ve padişahın tahttan indirilmesinin İslam hukukuna uygun olduğu belirtilmektedir.

Abdülhamit'in 27 Nisan 1909'da tahttan indirilmesiyle birlikte yerine kardeşi Veliaht Mehmet Reşat Efendi'yi getiren Meclis, bu kararı Abdülhamit'e bildirmek üzere dört kişilik bir kurul oluşturmuş̧tur ${ }^{125}$. Bu arada Abdülhamit, taht değişikliğini bildiren yüz bir pare top atışını duyunca artık her şeyin bittiğini anlamıştır. Sarayın küçük mabeyn denilen yerinde kuşku içinde beklerken, sözü edilen kurulun kendisini görmek istediği bildirilmiş ve kurula sarayı korumaya memur Galip (Paşa) Bey'de katılmıştı. Abdülhamit'e fetva kararını Esat Paşa, "Biz Mebuslar Meclisi tarafindan geliyoruz. Fetva var, millet sizi tahttan indirdi. Amma hayatıniz emindir" sözleriyle bildirmiş ve Abdülhamit ise metanetini koruyarak, "Bu işi ben yapmadım. Sebep olanlar millet arasın bulsun. Ben milletimin iyiliği için çok çalıştım. Hepsi mahvoldu. Hepsinin üstüne sünger çekildi. Kaderim böyle imiş. Sebep olanları varsin millet bulsun, yalnız bir ricam var oda hayatımın Çıră̆an Sarayı'nda muhafaza edilmesidir... Zaten ben yorulmuş idim. Hiçbir şey istemem, hiçbir şeye karışmam, milletten bunu rica ederim" ${ }^{126}$ diyerek son isteğini dile getirmiştir. Fakat kurulun, bu konuda söz söylemeye yetkili bulunmadı̆̆ını ve görevinin sona ermiş olduğunu söyleyerek saraydan ayrıldığı görülmektedir.

Buradan da anlaşılacağı üzere Abdülhamit, ağabeyi Sultan Murat'1 hapsetmiş olduğu Çırağan Sarayı'nda kalmak istemiş ama aynı günün gece yarısında gelen bir heyet Abdülhamit'e Selanik'e götürüleceğini ve hazırlanmasını bildirmiştir. Fakat O'nun öldürüleceğinden kuşkulanarak

${ }^{123}$ Meclis’e Başkanlık eden Sait Paşa “Erbâb-ı Hâll-ü akdan Murat devlet vükelâst değil midir" diyerek tahttan indirme işini Tevfik Paşa Hükümeti'ne yüklemek istemiş, ancak vükelâ, Padişahın vekilleri olduğuna göre müvekkillerini azledemeyecekleri düşüncesiyle bu işi üzerine almak istememiştir. Bunun üzerine milletvekilleri, hep bir ağızdan tahttan indirmeyi kabul ederek ulusun kudretini göstermek istemişlerdir. Kur'ân'ın emrettiği "Meşveret", İslam tarihinde "Erbâb-1 Hâll-ü Akd" denilen eşraf, oymak ileri gelenleri gibi söz ve nüfuz sahibi kimselerle danıșıp anlaşmak biçiminde uygulana gelmiştir. Bkz., Unat, s. 147.

${ }^{124}$ Fetvanın orijinal metni için bkz., Unat, s. 148.

${ }^{125}$ Adı geçen 4 kişilik kurul; ikisi Mebuslar Meclisi'nden, diğer ikisi de Ayân'dan olmak üzere olusturulmuștur. Ayân üyelerini temsilen Bahriye Feriki Arif Hikmet Paşa ile Ermeni Katolik Cemaatinden Aram Efendi; Mebusan'dan da Arnavutluk (Draç) Milletvekili Jandarma Livâsı (Tuğgeneral) Esat (Toptanî) Paşa ve Selanik Yahudi Cemaatinden Emanuel Karusu Efendi bulunuyordu. Bkz. Karal, C. IX, s. 106; Bayur, C. I, Ks. II, s. 212.

${ }^{126}$ Unat, s. 81; Hayat Tarih Mecmuası, Galip Paşa'nın Hatıraları, 1966, s. 8-9; Karal, C. IX, s. 107. 
Selanik'e gitmeyeceğini söylemesi ve iki tarafında isteklerinde direnmesi, trajik olaylara yol açmıştır'27. Bu arada Ali Galip Bey’in, "Koskoca şanlı bir ordu sizin hayatınız temin ediyor. Bu konudaki karar sizindir... Fakat bu teminatı İstanbul'da kalırsanız veremiyor, sorumluluk kabul etmeyiz" sözleri etkisini göstermiş ve başka çıkar yol kalmadığını anlayan Abdülhamit kaderine razı olmuştur. Küçük Şehzade Abdurrahim Efendi ile eşlerinden ve hizmetkârlarından bazılarını da yanına alan II. Abdülhamit, saraydan alınıp önce Sirkeci'ye, oradan da özel bir trene bindirilerek Selanik'e götürülmüştür ${ }^{128}$.

Böylece, Osmanlı tarihine damgasını vuran II. Abdülhamit dönemi bu olay ile kapanmış oluyordu. Abdülhamit'e tahttan indirildiğini bildiren dört kişilik kurulda Ermeni ve Yahudi milletvekillerinin de bulunması, ileri ki günlerde İttihatçıları büyük sıkıntılara sokacaktır. Çünkü bu durum gericilerin eline verilmiş büyük bir saldırı fırsatı olacaktır. Çünkü, Abdülhamit yalnızca padişah değil aynı zamanda halife olup tüm dünya Müslümanlarının dinsel önderidir. Ermeni ve Yahudi Milletvekilleri ise Halife-Padişaha tahttan indirildiğini bildiriyorlardı. İşte bu yanlışlık günümüze kadar uzanacak süreç içinde İttihatçıların şiddetle eleștirilmelerine, siyonistlikle suçlandırılmalarına ve gericiler eliyle bir "Ulu Hakan Abdülhamit Han" portresinin çizilmesine neden olacaktır ${ }^{129}$. İttihatçılara göre bunda bir yanlışlık yoktu. Abdülhamit'e bildirilmiş olan fetva değil, fetva üzerine Millet Meclisi'nin almış olduğu bir karardı. Bu kararında karakteri kesin olarak siyasaldı. Kurula ulema (din bilgini) sınıfından kimsenin seçilmemiş olması, eskiden bu sınıfa ait olan hakkın, bundan böyle Millet Meclisi'ne geçmiş olduğunu göstermek içindi. Daha açık bir ifadeyle, Meclisler tüm Osmanlı Devleti halklarını temsil ediyorlar, Osmanlı halkları ise salt Müslümanlardan değil, Hıristiyan ve Musevi vatandaşlardan oluşuyordu. Kurula Ermeni ve Yahudi üyelerinin seçilmiş olması, ayrıca Meşrutiyeti duyurmak ve 31 Mart Ayaklanması'nı bastırmak için birlikte çalışmış olan Osmanlıların birlikteliklerinin devam etmekte olduğunu göstermek maksadıyla yapılmıştı ${ }^{130}$.

31 Mart İsyanı'nı bastıran Hareket Ordusu'nun duruma hâkim olduğunu gören ayaklanmacıların birer, ikişer İstanbul'dan ve Osmanlı ülkesinden kaçabilmenin yollarını aradıkları görülmektedir. Kaçanların başında ise Volkan Gazetesi ve İttihâd-1 Muhammedi Cemiyeti kurucusu Derviş Vahdeti, Kâmil Paşa-zâde Sait Paşa, Abdullah Zühtü, Áli Kemal, Berât Milletvekili İsmail Kemal, Serbestî Gazetesi Baş yazarı Rifat Bey, Ergiri

${ }^{127}$ Bu trajik ortamda haremdeki kadınlar ve Padişahın yanında bulunan oğlu Şehzade Abdurrahim Efendi ağlamaya başlamıs ve Başkatip Cevat Bey ise adeta şoka girmiști. Ayrıca Harem kapısından askerlerin yukarıya çıkmaya başlaması bu şaşkınlığı büsbütün arttırmıştır. Bkz., Karal, C. IX, s. 107.

${ }^{128}$ Karal, C. IX, s. 107-108; Bozdağ, Sultan Abdülhamit'in Hatıra Defteri, s. 118-119.

${ }^{129}$ Çağlar Kırçak, Messrutiyetten Günümüze Kadar Gericilik, s. 59; Atılhan, s. 227-228.

${ }^{130}$ Karal, C. IX, s. 106-107; Kırçak, Meşrutiyetten Günümüze Kadar Gericilik, s. 60. 
Milletvekili Müfit, Ahrar Partisi Genel Sekreteri Nurettin Ferruh Beyler bulunmaktadır ${ }^{131}$.

Olayların sona ermesiyle İstanbul'da sıkıyönetim ilan edilerek, isyana karışanların tespiti yapılmış ve geniş çapta tutuklamalar başlamıştır ${ }^{132}$. Ayrıca suçluların yargılanarak cezalandırılması amacıyla üç Divan-1 Harp (Askeri Sıkı Yönetim Mahkemesi) oluşturulmuş ve tutuklananların ilk sorgulamalarını yapmak üzere Tahkik Heyetleri (Araştırma Komisyonları) ile halkın bu olaylara karıșan kimseler hakkında bildiklerini haber verebilmesi için Tedkikât Heyetleri (İnceleme Komisyonları) kurulmuştur ${ }^{133}$.

Olayların çıkmasında birinci derecede aktif rol oynayan Derviş Vahdeti, bu ayaklanmayı hazırlamak için elinden gelen bütün kuvveti harcamış, kurmuş olduğu İttihâd-1 Muhammedi Partisi ve onun yayın organı olan Volkan gazetesi, diğer muhalefet partileri ve basını İttihat ve Terakki Partisi'ne karşı kışkırtmada başarılı olmuştu. Ayrıca, bütün bu bozguncu faaliyetlerinde Kıbrıslı Kâmil Paşa ile İngiliz ajanları tarafından desteklenmişti ${ }^{134}$. Derviş Vahdeti, Hareket Ordusu'nun İstanbul'a girmesiyle birlikte önce İngilizlerin adamı Sait Paşa'ya başvurmuş ve O'nun tavsiyesiyle Şehzade Vahdettin'in Sarayına sı̆̆ınmak istemiștir. Şehzadenin ret cevabı üzerine Gebze'ye kaçmıştır. Kıyafet değiştirerek Gebze'den yola çıkan Vahdeti'nin niyeti İzmir'e gitmek ve Ege'den yabancı bir ülkeye kaçmaktı. Fakat trende iki subayın kendisinden şüphelenmesi üzerine, Hereke'de inmiş ve yollarda konaklayarak Bergama'ya gelmiștir. Oradan İzmir'e geçen Vahdeti, para bulmak için başvurduğu bir hemşehrisi tarafından ihbar edilerek yakalanmış ve İstanbul'a gönderilmiştir ${ }^{135}$. 18 Mayıs tarihli Tanin gazetesi, Volkan gazetesi sahibinin Aleksandros Vapuru ile İstanbul'a getirilişini şöyle anlatmaktadır ${ }^{136}$ :

"Vapur rıhtıma yanaşır yanaşmaz Vahdeti'nin kötü ayağından olacak ki hava birdenbire karardı. Fırtına şiddetlendi, yağmur yağdı. $B u$ vatan hainini görmek üzere kadın-erkek birçok kişi rıhtımın üzerinde idi... Orta boylu, biraz şişmanca, sakalını makine ile kestirmiş, saçları alelâde, başında bir püskülsüz fes, arkasında ise aba vardl, şalvar giymişti. Yüzünde pişmanlık işareti görülmüyordu... Gericilerden Çerkez Salih'le, medrese ögrencilerinden Ahmet Hilmi

${ }^{131}$ Güresin, s. 69-70.

${ }^{132}$ Tutuklananlar arasında Prens Sabahattin Bey, Mizancı Murat Bey, Osmanlı gazetesi sahibi Ahmet Fazlı Bey vardır. Fakat Sabahattin Bey ile Ahmet Fazlı Bey daha sonra serbest bırakılacaktır. Bkz., Güresin, 31 Mart İsyanı, s. 70.

${ }_{133}$ Birinci Sıkı Yönetim Mahkemesi Tophane Nazırı Hurşit Paşa'nın, İkincisi Topçu Livası Hasan Rıza Paşa'nın, Üçüncüsü de Nazif Paşa'nın başkanlıkları altında kurulmuștu. Bkz. Mustafa Müftüoğlu, Her Yönüyle Sultan II.Abdülhamid, İstanbul, CCile Yayınları, 1985, s. 338; Cüneyt Marmara, "31 Mart Vak'ast", (Istanbul Üniversitesi Atatürk Illkeleri ve Inkilap Tarihi Enstitüsü, Basılmamıs Yüksek Lisans Tezi, İstanbul, 1999.), s. 110.

${ }_{134}$ Vahdeti'nin, Avcı Taburları arasında kışkırtıcı faaliyetlerde bulunduğu bazı İngiliz kaynaklarında da açığa vurulmaktadır. Bkz., Sir Edwin Pears, Forty Years In Constantinople, London, 1916; Karal, C. IX, s. 119.

${ }^{135}$ Güresin, s. 71-72.

${ }^{136}$ Tanin Gazetesi, 18 Mayıs 1909, s. 1; Güresin, s. 72. 
beraberinde idiler. Vapurdan çıkarılıp önce Saray Burnu'ndaki askerlik dairesine, oradan da Divan Yolu'nu takiben Harbiye Nezareti'ne götürüldü..."

İsyanın bastırılmasıyla Askeri Sıkı Yönetim Mahkemelerinde yargılanan suçluların cezaları verilmeye başlanacaktır. Nitekim, mahkemenin verdiği ilk idam kararı 3 Mayıs 1909'da çıkmış ve isyanda önemli rol oynayan çavuşlardan 13 kişi asılarak cezalandırılmıştır ${ }^{137}$. Bunun yanı sıra Divan-1 Harbin değişik tarihlerde vermiş olduğu kararlara göre, suçu sabit görülen 62 isyancı idama, 37 isyancı ömür boyu hapis ve kal'abentliliğe (kale içinde yaşamaya mahkûm edilme), 390 isyancı hapis ve 139 isyancı da sürgün cezasına çarptırılmıştır. İdam edilenler arasında yaverlerden Kabasakal Mehmet Paşa, Erzurum Garnizon Komutanı Yusuf Paşa, Abdülhamit'in Ser-Musahibi Cevher Ağa, Taşkışla Taburları Komutanı İsmail Hakkı Bey ve Volkan Gazetesi sahibi Derviş Vahdeti de bulunuyordu ${ }^{138}$. Derviş Vahdeti'nin yargılanması bir aydan fazla sürmüş ve kendisini kurtarmak için bir hayli çaba göstermiş, sonunda Hareket Ordusu Komutanlığı'na vermiş olduğu bir dilekçe ile deli olduğunu ileri sürerek, mahkemenin bu durumu göz önünde bulundurmasını talep etmişti ${ }^{139}$. Fakat Vahdeti'nin karakteristik özelliklerinden birisi de ortamına göre her kalıba girmesidir. Hele ucunda para ve can olunca söylediklerinin tam tersini de yapmaya hazırdı. Vahdeti'nin bütün bu çabaları ve çırpınışları kendisini kurtarmaya yetmemiş ve daha birkaç hafta önce zehir saçan söylevler verdiği Ayasofya Meydanı'ndaki bir dar ağaçta can vermiştir.

Derviş Vahdeti’yi idama götüren Sıkıyönetim Mahkemesi'nin kararında da açıkça görüleceği üzere ${ }^{140}$, Vahdeti aslında hemen her şeyi yapabilecek özelliklere sahip ve son derece tehlikeli biri olarak değerlendirilmektedir. İstanbul'un belli başlı meydanlarında kurulan sehpalar da Derviş Vahdeti

${ }^{137}$ Nazım Paşa ve Aslan Beyi öldüren Hamdi Yaşar ve Hazım Çavuşlarla birlikte 5 erat Ayasofya'da, askeri isyanı kışkırtan diğer 5 çavuş ve onbaşı Beyazıt'ta, Teğmen İlyas Bey'i şehit eden 3 er ise Köprü'de idam olunmuştur. Bkz. Güresin, 31 Mart İsyant, s. 70.

${ }_{138} 12$ Mayısta Ayasofya'da asî askerlerle iș birliği yapan polis ve subaylardan 5 kiși 27 Mayıs'ta; çoğunluğu saraya mensup olan ve isyanla yakından ilgisi görülen Ser-Muhasib Cevher Ağa, Tütün Kıyıcısı Mustafa Ağa, Tüfekçi Miralay Halil Bey, Şurâ-yı Devlet Azasından Tayyer Bey, Rusûmat İstatistik Kalemi Müdür Yardımcısı Tevfik Bey, Enderunlu Lütfi Bey olmak üzere 15 kişi, Köprü, Beşiktaş ve Beyazıt'ta idam edilmişlerdir. 19 Temmuz'da ise, 4'ü Ayasofya'da, 5'i Beyazıt'ta ve 4'ü de Fatih'te olmak üzere 13 kişi daha idam edilmiștir. Bunlar arasında da Dervis Vahdeti başta olmak üzere matbaaları yağma edenleri teşvik eden İttihâd-ı Muhammedi Cemiyeti'nin önemli azalarından Yüzbaşı Behçetzâde Hakkı ve Romülüs İspatari'yi katleden Dördüncü Avcı Taburundan İzmirli Kaim, Abdülhamit'in eski yaverlerinden Kabasakal Cerkez Mehmet Paşa ve Erzurum'da askeri isyana teşvik eden Yusuf Paşa gibi önemli şahıslar bulunmaktadır. Bkz. Ecvet Güresin, 31 Mart isyant, s. 70-71.

${ }^{139}$ Derviş Vahdeti'nin, Hareket Ordusu Komutanlığı'na yazmış olduğu dilekçede, "İrsî olarak asabi nöbetler geçirdiğim için çoğunlukla yazdığım şeylerin faydasını ve zararını düşünemeyecek durumda bulunduğumu, sıkı yönetim kumandanlığına bildirmiştim. Nazara almadılar. Bunu adalet adına söylemek zorunluluğundayım." şeklinde ifadesi, ruhi bir dengesizliği ortaya koymaktadır. Fakat bu dengesizliğin yanında hırslı olduğu ve kendisini çok kurnaz zannettiği de bilinmektedir. Bkz., Güresin, s. 72-73.

${ }^{140}$ Sıkıyönetim Mahkemesinin Kararı için Bkz. Güresin, s. 73-74. 
başta olmak üzere olaya karışanların cesetleri teşhir edilmiştir. Bundan başka Yıldız'da geniş çapta araştırmalar yapılarak olaya karışan pek çok kişi muhtelif yerlere sürülmüş ve isyan sırasında taassupları kabartılarak, para ile kandırılarak irtica bayrağını açan taburların askerleri de cezalandırılmaktan kurtulamamışlar, yollarda çalıştırılmak üzere Rumeli'ye sevk edilmişlerdir ${ }^{141}$. Sıkıyönetim Mahkemelerinin çalışması 23 Temmuz 1909 tarihine kadar sürmüş ve bu tarihte yayınlanan bir tebliğde gelişmeler şöyle değerlendirilmektedir ${ }^{142}$ :

"Irtica fiillerinde ön ayak olanlar zaten mevkûf olup Divan-l Harpçe verilen âhz-u girift kararlarının hükümleri mahfûz kalmak, Hareket Ordusu'nun muvâsalâtı üzerine gerek ecnebi memleketlere, gerek dahile kaçanlar hakkında takibât icra edebilmek, şahsi haklar müstesna olmak ve ancak yeni vak'âlar olursa bunlara bakllmak üzere, 31 Mart Vak'âsı'ndan dolayı artık memleketin hiçbir tarafinda hiçbir kimse hakkında takibât ve suâl vâki olmaması hakkında Divan-t Harpçe verilen karar üzerine irâdei seniyye sâdır olmuştur."

\section{31 Mart Olayı ve Kamuoyu Tepkileri}

31 Mart Olayı ile ilgili olarak en geniş yorumların İttihâd-ı Muhammedi Partisi'nin yayın organı olan Volkan gazetesinde yapıldığı görülmektedir. Volkancılar, olayı sevinçle karşılayarak Cemiyetlerinin büyük bir zaferi olarak değerlendirmişlerdir ${ }^{143}$. Volkancı görüşleri devam ettiren bir çok gazetede aynı tezleri savunmuştur ${ }^{144}$ : "Meşrutiyet tehlikede değildir. Bilâkis tehlikede olan Meşrutiyeti şanlı askerler kurtarmıştır. İttihatçı zulmü son bulmuştur..."

Nitekim hemen bütün muhalif basın, halk nazarında ne olduğu belli olmayan şeriatı, "yaşasıs" nidalarıyla selamlamıştır. Serbesti gazetesinde Ayan-zâde M. Süleyman, "Hakikat gizlenemez...Yaşasın Meşrutiyetin tek koruyucusu olan şeriatımız" ve Mizan gazetesinde Murat Bey'in, "Osmanl askerlerinin dünya tarihinde görülmemiş bir kahramanlı gösterdiğini”" dile getirdiği görülmektedir $^{145}$.

Ahrar Partisi'nin yayın organı olan "Osmanll" gazetesi ile Prens Sabahattin Bey'in beyannamelerinde de, 31 Mart Olayı'nın desteklendiği açıkça görülmektedir. Özellikle Sabahattin Bey, olayda din adamları ve askere başarı temennisinde, çeşitli tavsiyelerde ${ }^{146}$ bulunmaktadır. Bu

\footnotetext{
${ }^{141}$ Marmara, 31 Mart Vak'ast, s. 35.

${ }^{142}$ Mustafa Baydar, 31 Mart Vak'ası, İstanbul, Milli Tesanüd Birliği Yayınları, 1955, s. 34-37.

${ }^{143}$ İttihâd-1 Muhammedi Gebze Şubesi'nin bir mektubunda " 31 Mart Olayı, Meşrutiyet Inkılabını tamamlayan sosyal ve dini bir harekettir. Zira Meşrutiyetin başından beri İlam milleti üzerine çökmüs olan zulüm ve istibdat, bu dini inkllap ve Tanrı kudretiyle kahredilmiştir." şeklinde ifadeler yer almaktadır. Bkz. Volkan Gazetesi, No. 148, 1325, s. 4.

144 Tunaya, İslamcilık Akımı, s. 133.

${ }_{145}$ Tunaya, s. 133; Serbesti Gazetesi, "Hakikat Gizlenemez", 2 Nisan 1325, s. 1; Mizan Gazetesi, "İnkılab-1 Sahih ve Teşekkürat", 1 Nisan 1325.

${ }^{146}$ Tunaya, s. 134.
} 
görüşlerde olan gazeteler, isyan süresince mevcut olan anarşi havasını toz pembe gösterme yoluna gitmişler ve İttihatçıların iktidardan uzaklaştırılması ümidini bu isyana bağlamışlardır. Örneğin Ahmet Cevdet Bey'in çıkarmış olduğu "Íkdam" gazetesi, bu isyanın çıkışından son derece memnun olup sadece meşrutiyetin devamını istemektedir. Ancak istediği İttihat ve Terakkisiz bir Meşrutiyettir. Aynı gazetenin olayları verirken Bakanların bile öldürülüşünü basit bir olay gibi göstermesi de son derece ilginçtir. Bunun yanı sıra bütün cinayetler yanlış anlama sonucu kaza ile meydana gelmiş ve askerler büyük üzüntü duymuşlardır ${ }^{147}$.

Mevlân-zâde Rıfat Bey'in çıkarmış olduğu Serbesti gazetesi 'de, Hasan Fehmi Bey'in öldürülmesinden hemen sonra İttihat ve Terakki Cemiyeti'ne ve teşkilatına karşı şiddetli bir kampanyaya giriştiği görülmektedir. Gerçi Serbesti, İttihâd-1 Muhammedi Cemiyeti'ni desteklememiş ama yazılarıyla isyancıları mükemmel bir şekilde tahrik etmiştir. Bu gazeteyi "Volkan" takip etmiş ve gazete de çıkan ilanlar ile Derviş Vahdeti"nin öğütleri bu bağlantıyı açık bir şekilde ortaya koymaktadır ${ }^{148}$ :

“Umum asker karındaşlarımıza nasihat... I Nisan'da Meclis binası önünde içtima eden asâkir-i şahânenin fikirleri herkesçe malum olmuştur. Allahın yardımıyla arzumuza nail olduk ve bu harekâtımızı ecnebi devletlere vartncaya kadar takdir ettirdik. Şükürler olsun, askerlik adına şu kazanmış olduğumuz nam-ı celil ile iftihar etmeliyiz..."

İsyan ile ilgili basında çıkan bu haberlerin, Hareket Ordusu'nun İstanbul'da duruma hâkim olmasıyla birlikte tamamen değiștiği görülmektedir. Volkan gazetesinin başyazarı Derviş Vahdeti kurtuluşu kaçmakta bulmuş ve İkdam gazetesinin yazıları da, on-on beş gün öncekilerin tamamen tersi olmuştur. Nitekim İkdam gazetesinin 2 Mayıs 1909 tarihli nüshasında, "Yaşasıın Ordu" başlıklı makalede, duruma hâkim olan Hareket Ordusu büyük bir sevinçle alkışlanarak övülmektedir ${ }^{149}$.

Buradan da açıkça görülmektedir ki, kısa bir süre önce yazılarda iğrenç sözlerle karalanan subaylar göklere çıkartılmaktadır. 31 Mart'ta basının durumu ve genel değerlendirmesini Hüseyin Cahit (Yalçın) Bey, "31 Mart'ta Türk Basını Sıfır Aldı" başlıklı yazısında açık bir şekilde ortaya koymaktadır ${ }^{150}$ : Karaktersizlik ve dalkavukluk!.

${ }^{147}$ Güresin, s. 78-79.

148 Güresin, s. 81-82; Volkan Gazetesi, 5 Nisan 1325, s. 1.

149 Adı geçen gazetede, “...bu fedakâr gönüllülerin son hürriyet savaşı sırasında gösterdikleri çabayı ve büyüklü̆ğ̈ Mahmut Sevket Paşa Kumandasında İstanbul surlarında ifa ettikleri vatan hizmetini yad etmek, bizim için en büyük, en önemli bir görevdir... Binâenaleyh vatan istibdattan kurtaran, milleti saadete götüren etkenleri incelediğimiz zaman bir yüksek kuvveti, silahl kuvvetleri takdis etmemiz gerekir ki, o da muzaffer ordumuz. şanlı subaylarımızdır." şeklinde bir ifade yer almaktadır. Bkz. Ikdam Gazetesi, "Yaşasın Ordu", 2 Mayis 1909, s. 1; Güresin, 31 Mart İsyanl, s. 82-83.

iso Isyan sırasında büyük tehlikeler atlatan, bir Rus vapuruyla önce Odesa'ya kaçıp, oradan da Selanik'e giden Hüseyin Cahit (Yalçın) Bey, Türk basınının durumunu şöyle özetlemektedir: "...Türk basınının en acl, en yüz karası bir ahlâk yarasının üzerine 


\section{SONUC}

31 Mart Ayaklanması, ülkede kişisel çıkarları için şeriatı egemen kılmak isteyen bir avuç din sömürücüsünün yarattığı bir olay olarak değerlendirilebilir. Bu olayda, hem bir takım tahrikler ve bu tahrikleri yapan kişiler, topluluklar vardır. Ayrıca o günkü şartlar, olayın meydana gelişinde başlıca rolü oynamıştır. Bu nedenle adı geçen isyanı tek boyutlu ve düzenli olarak değil, çok boyutlu olarak görmek gereklidir. Yine bilindiği üzere tahriki yapan ve İslamcılık akımını cihat parolasıyla sokaklara döküp, silahlı çatışmaya götüren İttihâd-1 Muhammediciler ile bunların yayın organı Volkancılardır. Fakat Volkancıların arkasında da dış ülkelerin gizli teşkilatlarının parmağı olduğundan şüphe yoktur. Nitekim bu şüpheler duruşmalar sırasında kuvvetlenmiş, fakat başta Mahmut Şevket Paşa olmak üzere bazı İttihatçıların, Batılı Devletlerle arayı bozmamak için soruşturmaya izin vermedikleri görülmektedir ${ }^{151}$.

O günlerin lider emperyalist devleti olan İngiltere'nin Kıbris'ta yetiştirdiği Derviş Vahdeti'nin, 31 Mart öncesi Volkan gazetesinde yazdıklarının dikkatli bir şekilde incelenmesi, 31 Mart şeriatçılığının rengini gözler önüne sermektedir. Nitekim, 15 Aralık 1908 tarihli Volkan gazetesi, İngilizlerin adem-i merkeziyetçiliği sayesinde Kıbrıs'ın “küçük bir İsviçre kenti" haline geldiğini ileri sürmektedir. Bütün Müslümanları şeriat bayrağı altında birleştirme iddiasında bulunan Vahdeti, İngiliz efendilerinin Abdülhamit tipi şeriatçılık ve Panislamizm'den, Hindistan ve Mısır Müslümanlarını ayaklandırır endișesiyle bir ara fena halde ürktüklerini bilmektedir. Bu nedenle, Vahdeti'nin İttihâd-1 Muhammedisi sınırlı bir Panİslamizm hareketidir. Hatta Vahdeti, İngiltere'nin dostu olduğu için Rusya'yı da korumakta ve Rusya Müslümanlarını İttihâd-ı Muhammedi egemenliği dışında tutmaktadır ${ }^{152}$. Vahdeti'ye göre, Rus çarı ve İngiliz Kralı İslam'ın dostlarıdırlar. Düşman ise, İngiliz dostluğuna inandığı halde milliyetçi eğilimlerle İngiliz politikasına az çok karşı çıkan İttihat ve Terakki'dir. İttihatçılar, 31 Mart Olayı'nda ünlü “Intelligence Service"ne mensup İngiltere Büyükelçiliği Baş Tercümanı Fitz Maurice ile hizmetindeki yerli işbirlikçilerin faaliyetlerini tespit etmişler, ama bu konuyu kurcalamaktan kaçınmışlardır ${ }^{153}$.

parmağımızı koymuş oluyoruz. Karaktersizlik ve dalkavukluk!...Gazetecilik her sabah halktan adeta onar para dilenerek cep doldurmaya yarar bir vasitadan ibaretti... Vicdani kanaat, prensip, ahlâk, meslek bunlar boș lâflardı. Hakikât yalnız kara bir meteliktir. İşte 31 Mart Olayı'nda kendini gösteren basın, 31 Mart'tan hemen sonra hüküm ve nüfuz ayak takımının, asi neferlerin elindeydi. 'Íkdam' onları alkısllyor, daha önce ise Abdülhamit'in düdüğü ötüyordu. Türk basını O'nun bendesi idi. 10 Temmuz'dan sonra Cemiyet korkusu kalkınca menfaat başka tarafta aranır oldu..." Güresin, s. 84-85.

${ }_{151}$ Güresin, 31 Mart İsyanı, s. 85. $14-15$.

${ }^{152}$ Doğan Avcıoğlu, 31 Martta Yabancı Parmağı, I.B., Ankara, Bilgi Yayınevi, 1969, s.

${ }^{i 53}$ Dikkati çeken bir nokta ise, İngilizlerin bu isyanda oynadıkları rolü örtbas etmek için konu ile ilgili pek çok belgeyi yayınlamaktan kaçınmalarıdır. Ayrıntılı bilgi için bkz., Avcıŏ̆lu, s. 16. 
Bu olayın sonucunda birçok kimse cezalandırılmış ama olayda önemli rol oynayan bazı kimseler gözden kaçmış veya kaçırılmış gibi görünmektedir. Örneğin Prens Sabahattin'in sözü edilen ayaklanmadaki rolü oldukça karanlıktır. Fakat bilinen şudur ki Prensin kurdurmuş olduğu Ahrar Partisi'nin eylemleriyle ayaklanmanın başarıya ulaşmasında kendisine bir pay çıkarmış olduğunu, Serbesti gazetesi sahibi Mevlân-zâde Rifat Bey'e söylemiş olduğu şu sözlerinden anlaşılmaktadır ${ }^{154}$ : "İ̧ste biz durur, durur da siyaset meydanına böyle atılirız."

Prens Sabahattin'in cezalandırılmaktan İngiliz Büyükelçiliği aracılığı ile kurtulması ${ }^{155}$ her şeyi doğrulamaktadır. Yaygın olan düşünce İngilizlerin baskısı veya ricasıyla serbest bırakılmasıdır. Yine İttihâd-1 Muhammedi Cemiyeti kurucu üyelerinden ve ateşli savunucularından birisi olan Said-i Nursi (Kürdi), kader arkadaşı ve isyanın baş mimarı olan Derviş Vahdeti'nin asılmasına rağmen kendisi kurtulmuştur. Ayasofya'da konuşmalarıyla halkı tahrik ederek, isyana teşvik eden bu kişinin idamdan kurtulması düşündürücüdür. Nitekim, günümüzde hâlâ bu gibi adamların ektikleri kötülük tohumlarının yeşertilmeye çalışıldığı görülmektedir.

\section{KAYNAKÇA}

Akşin, Sina, 31 Mart Olayı, Ankara, AÜ. SBF. Yayınları, 1970.

Akşin, Sina, Jön Türkler ve İttihat Terakki, 2. B., Ankara, İmge Kitabevi, 1998.

Atılhan, Cevat Rifat, Bütün Çıplaklı̆̆ı İle 31 Mart Faciası, 5. B., İstanbul, Bahar Yayınevi, 1972.

Avcıoğlu, Doğan, 31 Martta Yabancı Parmağı, I. B., Ankara, Bilgi Yayınevi, 1969.

Bayar, Celal, Ben de Yazdım, C. I, İstanbul, Baha Matbaası, 1966.

Baydar, Mustafa, 31 Mart Vak'ası, İstanbul, Anıl Matbaası, 1955.

Bayur, Yusuf Hikmet, Türk inkılabı Tarihi, C. I, Ks. II, Ankara, TTK., 1991.

Bozdağ, İsmet, Sultan Abdülhamit'in Hatıra Defteri, 10. B., İstanbul, Pınar Yayınları, 1995.

Cumhuriyet Gazetesi, "Halil menteşe'nin Hatıraları", 13 Ekim - 11 Aralık 1946, s.2.

Cumhuriyet Gazetesi, Halil Menteşe'nin Hatıraları, 22 Ekim 1946, s. 2.

Çandar, Tevfik, Ittihat-Terakki, İstanbul, İletişim Yayınları, 1991.

Ergün, Mustafa, Atatürk Devri Türk Eğitimi, Ankara, DTCF Yayınları, 1982.

Esatlı, Mustafa Ragıp, İttihat ve Terakki, İstanbul, Hürriyet Yayınları, 1975.

${ }^{154}$ Karal, C. IX, s. 118-119.

${ }^{155}$ Prens Sabahattin'i 31 Mart'ta Fitz Maurice'in alet olarak kullandığı bilinmektedir. Bkz., Rauf Orbay, Cehennem Değirmeni Siyasi Hattralarım, C. II, İstanbul, Emre Yay., 1993, s. 12; Avcıoğlu, 31 Martta Yabancl Parmağı, s. 80. 
Güresin, Ecvet, 31 Mart İsyanı, İstanbul, Habora Kitabevi, 1969.

Hayat Tarih Mecmuası, "Tarih Postası” Hayat Yayınları, C. II, (1.10.1966), s. 9, 97.

Hayat Tarih Mecmuası, "Galip Paşa'nın Hatıraları", Hayat Yayınları, C. II, (1.10.1966), s. 8-9.

İkdam Gazetesi , "Yaşasın Ordu", 2 Mayıs 1909, s. 1.

Íkdam Gazetesi, 27 Mart 1325 (9 Nisan 1909), s. 2.

İnan, Ali Mithat, Atatürk'ün Not Defterleri, Ankara, Gündoğan Yayınları, 1996.

Karal, Enver Ziya, Osmanlı Tarihi, İkinci Meşrutiyet ve Birinci Dünya Savaşı (1908-1918), C. IX, 3. B., Ankara, TTK., 1988.

Kırçak, Çağlar, Meşrutiyetten Günümüze Gericilik, 2. B., Ankara, İmge Kitabevi, 1994.

Kutay, Cemal, "Kanlı Neticelerinin 58 nci Yıldönümünde Otuz Bir Mart'ın Gerçek Suçlusu Kim?”, Tarih Konuşuyor, C. 7, No. 39, (Nisan 1967), s. 3131 - 3133.

Marmara, Cüneyt, "31 Mart Vak'asi”, (İstanbul Üniversitesi Atatürk İlkeleri ve Inkılap Tarihi Enstitüsü, Basılmamış Yüksek Lisans Tezi, İstanbul, 1999.), s. 110.

Mizan Gazetesi, "İnkılab-1 Sahih ve Teşekkürat”, 1 Nisan 1325, s. 1.

Mizan Gazetesi, 27 Mart 1325 (9 Nisan 1909), s. 2.

Müftüoğlu, Mustafa, Her Yönüyle Sultan II.Abdülhamid, İstanbul, Çile Yayınları, 1985.

Orbay, Rauf, Cehennem Değirmeni Siyasi Hatıralarım, C. II, İstanbul, Emre Yay., 1993.

Özalp, Kazım ve Teoman Özalp, Atatürk'ten Anılar, 4. B., Ankara, Türkiye İş Bankası Kültür Yayınları, 1998.

Pears, Sir Edwin, Forty Years In Constantinople, London, 1916.

Serbesti Gazetesi, "Hakikat Gizlenemez", 2 Nisan 1325, s. 1;

Serbesti Gazetesi, 27 Mart 1325 (9 Nisan 1909), s. 1.

Tanin Gazetesi, 10, 11, 15 Mayıs ve 4-11 Haziran 1925 tarihli sayılar.

Tanin Gazetesi, 18 May1s 1909, s. 1.

Tanin, 12 Ağustos 1908, s. 2.

Tunaya, Tarık Zafer, İslamcılık Akımı, İstanbul, Simâvi Yayınları, 1991.

Tunaya, Zafer Tarık, Hürriyetin İlanı İkinci Meşrutiyetin Siyasi Hayatına Bakışlar, 1. B., İstanbul, Bilgi Üniversitesi Yayınları, 2004. 
Unat, Faik Reşit, İkinci Meşrutiyetin İlanı ve Otuz Bir Mart Hâdisesi, II. Abdülhamid'in Son Mabeyn Başkâtibi Ali Cevat Bey'in Fezlekesi, 2. B., Ankara, TTK, 1985.

Volkan Gazetesi, "Derviş Vahdeti'nin Nutku”, 28 Mart 1325, s. 1.

Volkan Gazetesi, “İttihat ve Terakki Cemiyeti”, 26 Mart 1325, No: 81, s. 1.

Volkan Gazetesi, "Teskin-i Heyacân Muhal-1 Baş makale”, 1325, No. 102.

Volkan Gazetesi, 5 Nisan 1325, s. 1.

Volkan Gazetesi, Beyanname Sureti, 16 Mart 1909, s. 2.

Volkan Gazetesi, No. 148, 1325, s. 4.

Volkan Gazetesi, No: 49, 5 Şubat 1324, s. 1.

Volkan Gazetesi, "Derviş Vahdeti- Halife-i İslam Abdülhamit Hazretlerine açık Mektup”, 1325, No. 104, s. 1.

Yalman, Ahmet Emin, Yakın Tarihte Gördüklerim-Duyduklarım-Geçirdiklerim, C. I, İstanbul, Yenilik Basımevi, 1970. 